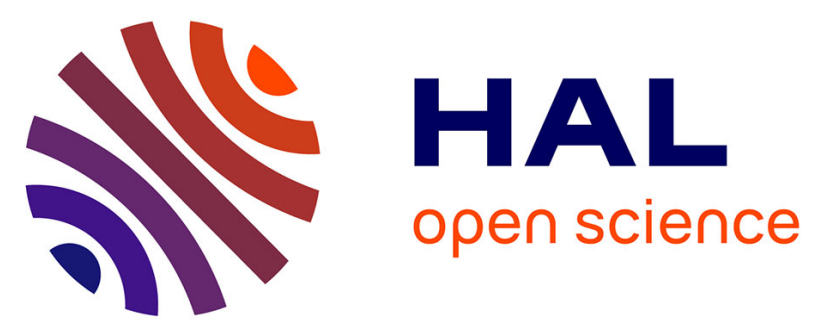

\title{
The influence of particle composition on Thorium scavenging in the Mediterranean Sea
}

M. Roy-Barman, C. Lemaitre, S. Ayrault, C. Jeandel, M. Souhaut, J.C.

Miquel

\section{- To cite this version:}

M. Roy-Barman, C. Lemaitre, S. Ayrault, C. Jeandel, M. Souhaut, et al.. The influence of particle composition on Thorium scavenging in the Mediterranean Sea. Earth and Planetary Science Letters, 2009, 286 (3-4), pp.526-534. 10.1016/j.epsl.2009.07.018 . hal-00437295

\section{HAL Id: hal-00437295 \\ https://hal.science/hal-00437295}

Submitted on 1 Mar 2021

HAL is a multi-disciplinary open access archive for the deposit and dissemination of scientific research documents, whether they are published or not. The documents may come from teaching and research institutions in France or abroad, or from public or private research centers.
L'archive ouverte pluridisciplinaire HAL, est destinée au dépôt et à la diffusion de documents scientifiques de niveau recherche, publiés ou non, émanant des établissements d'enseignement et de recherche français ou étrangers, des laboratoires publics ou privés. 
5 M. Roy-Barman (1) ${ }^{*}$, C. Lemaître (1,2), S. Ayrault (1), C. Jeandel (3), M. Souhaut (3), J.-C. Miquel

$6 \quad(4)$

8 (1) LSCE/IPSL Laboratoire CNRS/CEA/UVSQ, 91198 Gif-sur-Yvette Cedex, France

9 (2) LATMOS (IPSL/ UVSQ / CNRS / Paris VI), 75252 Paris Cedex 05, France

10 (3) LEGOS (CNRS/CNES/IRD/UPS), Observatoire Midi-Pyrénées, 14, Av. E. Belin, 31400

11 Toulouse, France.

12 (4) IAEA Marine Environment Laboratories, 4 Quai Antoine $1^{\mathrm{er}}$, MC-98000, Monaco

$19 *$ corresponding author : Phone: (33)1-69-82-35-66; Fax: (33)1-69-82-35-68;

20 E-mail address: Matthieu.Roy-Barman@1sce.ipsl.fr 
Abstract

Sediment trap data are crucial for the study of marine biochemical cycles but they need careful

23 validation by Thorium (Th) isotopes. In the present study, ${ }^{230} \mathrm{Th},{ }^{232} \mathrm{Th}$, Uranium (U), Aluminum (Al),

24 Barium $(\mathrm{Ba})$ and Manganese $(\mathrm{Mn})$ were analyzed in sinking particles collected by moored sediment

25 traps in the Ligurian sea (DYFAMED site) in order to determine the collection efficiency of the traps

26 and to constrain which particulate phase(s) carries Th isotopes in a region with strong lithogenic

27 inputs. The ${ }^{230} \mathrm{Th}_{\mathrm{xs}}$ evaluation was based on the $\mathrm{U}$ content of each sample rather than on the ${ }^{232} \mathrm{Th}$

28 content of each sample and the average ${ }^{238} \mathrm{U} /{ }^{232}$ Th ratio of the continental crust because the latter

29 method introduced too much uncertainty in the calculation. High trapping efficiencies $(187 \pm 85 \%$ at

$30200 \mathrm{~m}$ and $87 \pm 11 \%$ at $1000 \mathrm{~m}$ ) indicated no evidence of particle under-collection by the traps. The

31 lack of correlation between ${ }^{230} \mathrm{Th}_{\mathrm{xs}}$ and the carbonate or the organic matter fraction suggests that these

32 phases are not major ${ }^{230} \mathrm{Th}_{\mathrm{xs}}$-carrying phases in the deep ocean. For most samples of the time series,

33 the ${ }^{230} \mathrm{Th}_{\mathrm{xs}}$ concentration is correlated with the lithogenic fraction and the Mn concentration, but

34 pulses of particles with high lithogenic and Mn content and low ${ }^{230} \mathrm{Th}_{\mathrm{xs}}$ concentration occur in winter.

35 Assuming that ${ }^{230} \mathrm{Th}_{\mathrm{xs}}$ is only carried by lithogenic particles, we estimate $\mathrm{K}_{\mathrm{d} \_l i t h o}{ }^{\mathrm{Th}}$ ranges from $(0.42 \pm$

$360.04) \times 10^{7} \mathrm{ml} / \mathrm{g}$ to $(0.8 \pm 0.2) \times 10^{7} \mathrm{ml} / \mathrm{g}$. Assuming that ${ }^{230} \mathrm{Th}_{\mathrm{xs}}$ is only carried by authigenic $\mathrm{Mn}$

37 oxide precipitates $\left(\mathrm{MnO}_{2}\right)$, we estimate that $\mathrm{K}_{\mathrm{d} \_\mathrm{MnO} 2}{ }^{\mathrm{Th}}$ ranges from $(0.6 \pm 0.1) \times 10^{10} \mathrm{ml} / \mathrm{g}$ to $(1.1 \pm$

$380.4) \times 10^{10} \mathrm{ml} / \mathrm{g}$. The relative variation of $\mathrm{K}_{\mathrm{d} \_\mathrm{MnO} 2}{ }^{\mathrm{Th}}$ (a factor 7 ) between different oceanic sites is

39 significantly lower than the relative variation of $\mathrm{K}_{\mathrm{d}_{-} \text {litho }}{ }^{\mathrm{Th}}$ (a factor 50), suggesting that ${ }^{230} \mathrm{Th}_{\mathrm{xs}}$ has a

40 tighter link with $\mathrm{MnO}_{2}$ rather than with lithogenic particles and hence that ${ }^{230} \mathrm{Th}_{\mathrm{xs}}$ may be more likely

41 scavenged by $\mathrm{MnO}_{2}$ than by lithogenic particles. The unambiguous determination of the particles

42 carrying ${ }^{230} \mathrm{Th}_{\mathrm{xs}}$ remains to be done. 
45 Keywords: thorium, scavenging, sediment trap, trapping efficiency, marine particle, Mediterranean

46 Sea, DYFAMED

47 


\section{Introduction}

49 Understanding the oceanic carbon cycle requires reliable measurements of the particulate carbon

50 fluxes in the ocean. More generally, the quantification of particulate fluxes is a cornerstone of the

51 study of marine biogeochemical cycles. These fluxes are estimated with sediment traps. While

52 sediment trap data are very limited spatially and temporally for logistical and financial reasons, they

53 are critically important to tune the ocean biological pump in global biogeochemical models used to

54 evaluate the fate of the carbon cycle (Usbeck et al., 2003). However, turbulence around the trap

55 aperture can prevent a significant fraction of the sinking particles from being collected (Buesseler et

56 al., 2007). Therefore, it is critical to validate sediment trap data. Uranium (U) - Thorium (Th)

57 radioactive decay series are used to evaluate the efficiency of moored sediment traps (Bacon et al.,

58 1985). ${ }^{230} \mathrm{Th}$ is produced uniformly in the ocean by radioactive decay of ${ }^{234} \mathrm{U}$. Thorium is a very

59 particle-reactive element, so that ${ }^{230} \mathrm{Th}$ is rapidly scavenged on sinking particles and transported

60 toward the bottom of the ocean (Bacon and Anderson, 1982). If a trap works correctly, it should

61 collect an average ${ }^{230} \mathrm{Th}$ sinking flux equal to the production of ${ }^{230} \mathrm{Th}$ by radioactive decay of ${ }^{234} \mathrm{U}$

62 above the trap. As the ${ }^{230}$ Th flux collected by a sediment trap varies seasonally with the particle flux,

63 annually averaged fluxes are considered in order to cancel seasonal variations of the ${ }^{230} \mathrm{Th}$ flux that

64 reflect short-term departures from the longer-term steady state between production and removal of

$65{ }^{230}$ Th (Bacon et al., 1985). Yearly averaged trapping efficiencies (the ratio between the trapped flux of

$66{ }^{230} \mathrm{Th}$ and the radioactive production) as low as $10 \%$ have been obtained in surface waters and in the

67 mesopelagic zone (where horizontal currents are high) confirming that some traps largely undercollect

68 the particles (Guieu et al., 2005; Scholten et al., 2001). Very different evolutions of the particle flux

69 throughout the water column have been obtained when trapping efficiency corrections are used and

70 when they are ignored (Guieu et al., 2005; Scholten et al., 2001; Yu et al., 2001). Sediment traps may

71 also discriminate among different types of particles, with large and rapidly sinking particles expected 
72 to be collected more efficiently into the traps than small and slowly sinking particles (Buesseler et al., 73 1992). Therefore, a Th-based trapping efficiency may not be relevant for all particles and compounds

74 collected by the traps. Similar potential difficulties exist in paleo-oceanography with the

75 determination of sedimentary focussing/winnowing factors by the ${ }^{230} \mathrm{Th}$-normalisation method

76 (Adkins et al., 2006; Francois et al., 2004). Thus, the determination of the phase(s) carrying Th

77 isotopes is a key issue.

78 One way to address this question is to consider the correlations of ${ }^{230} \mathrm{Th}$ with the major phases

79 (carbonate, biogenic silica, lithogenic particles, organic matter) constituting the particles compositions

80 (Chase and Anderson, 2004; Chase et al., 2002; Luo and Ku, 2004a; Luo and Ku, 2004b; Roy-Barman

81 et al., 2005; Scholten et al., 2005). However, this method suffers from multiple correlations between

82 the different components of the marine particles producing spurious correlations between ${ }^{230} \mathrm{Th}$ and

83 some phases unrelated with ${ }^{230}$ Th scavenging, so that the result remains controversial. A recent work

84 has highlighted the possible role of minor phases such as Manganese (Mn) oxides on ${ }^{230} \mathrm{Th}$ scavenging

85 (Roy-Barman et al., 2005). However, it was based on a limited dataset that did not include samples

86 with very high concentration in lithogenic particles. Here, we present a set of sediment trap data

87 obtained at the DYFAMED site in the Ligurian Sea. This site receives sporadically a heavy load of

88 Saharan dust particles and the particle dynamics are particularly well documented (Migon et al.,

89 2002). Hence, this data set gives a good opportunity to test the Mn hypothesis in a lithogenic-rich

90 environment. It was also the opportunity to evaluate the collection efficiency of the traps at this site:

91 while the DYFAMED (DYnamique des Flux Atmosphériques en MEDiterranée) time series was

92 started in 1987, this evaluation has not been done yet.

93

94 2. Sampling and analytical methods 
The DYFAMED station (Fig. 1) is located in the western basin of the Mediterranean Sea, 30

97 nautical miles $(54 \mathrm{~km})$ off Nice $\left(43^{\circ} 25 \mathrm{~N}-07^{\circ} 54 \mathrm{E}\right.$, water depth: $\left.2330 \mathrm{~m}\right)$. Sinking particulate matter

98 was collected at $200 \mathrm{~m}$ and $1000 \mathrm{~m}$ from July 1999 to July 2000 as part of the DYFAMED sediment

99 trap time series. The traps were multisampling conical sediment-traps (Technicap PPS5) with a

100 collection surface of $1 \mathrm{~m}^{2}$. Sampling cups were poisoned with formaldehyde prior to trap deployment

101 in order to prevent grazing in the traps. The sampling interval was of 7 days, but in order to reduce the

102 number of analyses, composite samples were prepared with sampling steps ranging from 7 to 35 days

103 (a higher temporal resolution was used during high flux periods).

104

\section{2.2. Analysis of particulate phases}

106 Sampling procedures followed the JGOFS protocols and can be found elsewhere (Miquel et

107 al., 1994). Back in the laboratory, swimmers were removed from the samples. The whole sample was

108 then rinsed with ultra pure (MilliQ) and freeze-dried. Concentrations of total (TC) and organic (POC)

109 carbon were measured in Monaco in triplicates with a Vario-El CHN elemental microanalyzer on

110 aliquots of the desiccated samples. Aliquots of approximately $20 \mathrm{mg}$ of the desiccated samples were

111 digested in acid $\left(\mathrm{HNO}_{3}+\mathrm{HF}\right)$. Digestions were performed in a pressure-assisted microwave oven. For

112 all the acid-digested samples Barium (Ba) was analyzed by quadrupole ICP-MS (Perkin Elmer Elan

113 6000, LEGOS, Toulouse). Aluminum (Al), Mn and U concentrations were determined by quadrupole

114 ICP-MS (ThermoElectron XseriesII, LSCE, Gif sur Yvette).

115 Details on the material collected by the traps can be found at http:/www.obs-vlfr.fr/sodyf/.

116 Trapped particles are mainly composed of marine snow, detritus, fecal pellets and lithogenic particles

117 in variable proportions. The fraction of aluminosilicate is given by $\mathrm{f}_{\text {litho }}=(11.1 \pm 1.1) \times \mathrm{Al}($ in $\mathrm{g} / \mathrm{g})$. It 
118 corresponds to an $\mathrm{Al}$ content $(9 \pm 1) \%$ in the insoluble fraction of Saharan dusts of different origins

119 (Avila et al., 2007). The carbonate fraction was determined from Particulate Inorganic Carbon (PIC)

120 as follows: $\mathrm{f}_{\mathrm{CaCO} 3}=8.3 \times$ PIC by assuming that all PIC is associated to $\mathrm{CaCO}_{3}$. The organic matter

121 content is assumed to be twice the POC content: $f_{o m}=2 \times$ POC (Klaas and Archer, 2002). Biogenic

122 silica is known for not being a major ${ }^{230}$ Th scavenging phase in trapped material (Chase et al., 2002;

123 Roy-Barman et al., 2005). Therefore, it will not be considered in the following discussion. Excess Ba

$124\left(\mathrm{Ba}_{\mathrm{ex}}\right)$ was used to evaluate the abundance of biogenic $\mathrm{Ba}$ (Sternberg et al., 2007). It was obtained by

125 subtracting a $\mathrm{Ba}$ lithogenic fraction estimated with the $\mathrm{Al}$ content of the trapped material and a $\mathrm{Ba} / \mathrm{Al}$

126 ratio of $(6.7 \pm 1.0) \times 10^{-3} \mathrm{~g} / \mathrm{g}$ that corresponds to the insoluble fraction of Saharan dusts (Avila et al.,

127 2007). Mn was measured to evaluate the abundance of Mn oxides. The authigenic Mn fraction

$128\left(\mathrm{Mn}_{\text {auth }}\right)$ was obtained by subtracting a lithogenic fraction estimated with the $\mathrm{Al}$ content of the trapped

129 material and a $\mathrm{Mn} / \mathrm{Al}$ ratio of $(8.5 \pm 0.5) \times 10^{-3} \mathrm{~g} / \mathrm{g}$ that corresponds to the insoluble fraction of Saharan

130 dusts (Avila et al., 2007).

131

132 2.3. Analysis of ${ }^{230}$ Th and ${ }^{232}$ Th

$133 \quad{ }^{230} \mathrm{Th}$ and ${ }^{232} \mathrm{Th}$ were analyzed on an aliquot of the same solution obtained for major and trace

134 elements (see above). ${ }^{229}$ Th spike was added to this aliquot. After isotopic equilibration, the Th was

135 purified by ion exchange chemistry (Roy-Barman et al., 1996). Procedural blanks (around 20 pg of

$136{ }^{232} \mathrm{Th}$ and $0.1 \mathrm{fg}$ of ${ }^{230} \mathrm{Th}$ ) represent typically less than 1-2\% of the Th mass in the samples. The

137 samples were analyzed in Toulouse by MC-ICP-MS on a Neptune (Finnigan) instrument following a

138 procedure described previously (Guieu et al., 2005; Roy-Barman et al., 2005). The agreement between

139 the measured ${ }^{230} \mathrm{Th} /{ }^{232} \mathrm{Th}$ ratio and the recommended value (Banner et al., 1990) of a Th standard

140 indicates that the accuracy of the MC-ICP-MS measurement is typically better than $2 \%$. 


\section{3. Results}

143 The ${ }^{232}$ Th concentration ranges from $0.90 \pm 0.01 \mathrm{ppm}$ to $9.9 \pm 0.2 \mathrm{ppm}$ at $200 \mathrm{~m}$ and from 4.30 $144 \pm 0.02 \mathrm{ppm}$ to $9.4 \pm 0.1 \mathrm{ppm}$ at $1000 \mathrm{~m}$ (Tab.1). The ${ }^{230} \mathrm{Th}$ concentration ranges from $4.9 \pm 0.3 \mathrm{pg} / \mathrm{g}$ to $14546.3 \pm 0.7 \mathrm{pg} / \mathrm{g}$ at $200 \mathrm{~m}$ and from $28.8 \pm 0.6 \mathrm{pg} / \mathrm{g}$ to $47.0 \pm 0.6 \mathrm{pg} / \mathrm{g}$ at $1000 \mathrm{~m}$ (Tab.1).

146 The ${ }^{230} \mathrm{Th}$ produced by in situ decay of dissolved ${ }^{234} \mathrm{U}$ and that is scavenged on particles $147\left({ }^{230} \mathrm{Th}_{\mathrm{xs}}\right)$ is often calculated by subtracting the lithogenic ${ }^{230} \mathrm{Th}$ component to the total ${ }^{230} \mathrm{Th}$ :

$$
{ }^{230} \mathrm{Th}_{\mathrm{xs}}={ }^{230} \mathrm{Th}_{\text {measured }}-{ }^{232} \mathrm{Th}_{\text {measured }} \times\left({ }^{230} \mathrm{Th} /{ }^{232} \mathrm{Th}\right)_{\text {litho }}
$$

149 In previous studies of Th isotopes in the Mediterranean sea (Arraes-Mescoff et al., 2001; Roy-Barman

150 et al., 2002), a ratio $\left({ }^{230} \mathrm{Th} /{ }^{232} \mathrm{Th}\right)_{\text {litho }}=4.4 \times 10^{-6} \mathrm{~mol} / \mathrm{mol}$ was used based on a mean composition of

151 the continental crust (Andersson et al., 1995). However, in the present study, we have analyzed

152 samples with $\left({ }^{230} \mathrm{Th} /{ }^{232} \mathrm{Th}\right)$ as low as $(4.0 \pm 0.1) \times 10^{-6} \mathrm{~mol} / \mathrm{mol}$ at $200 \mathrm{~m}$ in winter (sample $\left.7 \mathrm{~B}\right)$. This

153 indicates that the value $\left({ }^{230} \mathrm{Th} /{ }^{232} \mathrm{Th}\right)_{\text {litho }}=4.4 \times 10^{-6} \mathrm{~mol} / \mathrm{mol}$ used in these earlier works is too high

154 because a negative ${ }^{230} \mathrm{Th}_{\mathrm{xs}}$ obtained with equation 1 would have no physical meaning. The ${ }^{230} \mathrm{Th} /{ }^{232} \mathrm{Th}$

155 ratio of the lithogenic material ranges typically from $3.2 \times 10^{-6}$ to $5.4 \times 10^{-6} \mathrm{~mol} / \mathrm{mol}$ (Anderson et al.,

156 1990). The ${ }^{230} \mathrm{Th} /{ }^{232} \mathrm{Th}$ ratio of aerosols collected in Monaco ranges from $(4.6 \pm 0.1) \times 10^{-6}$ to $(7.4 \pm$

$1570.1) \times 10^{-6} \mathrm{~mol} / \mathrm{mol}$ (Pham et al., 2005). Using these average values to correct for the lithogenic ${ }^{230} \mathrm{Th}$

158 would also produce negative ${ }^{230} \mathrm{Th}_{\mathrm{xs}}$ for numerous samples.

Alternatively, ${ }^{230} \mathrm{Th}_{\mathrm{xs}}$ can be determined if the lithogenic $\mathrm{U}$ content $\left({ }^{238} \mathrm{U}_{\text {litho }}\right)$ of the sample is

160 known, assuming that in this lithogenic material ${ }^{230}$ Th should be at secular equilibrium with ${ }^{234} \mathrm{U}$ and

$$
{ }^{230} \mathrm{Th}_{\mathrm{xS}}={ }^{230} \mathrm{Th}_{\text {measured }}-{ }^{238} \mathrm{U}_{\text {litho }} \times\left(\lambda_{230 \mathrm{Th}} * \mathrm{~m}_{230 \mathrm{Th}}\right) /\left(\lambda_{238 \mathrm{U}} * \mathrm{~m}_{238 \mathrm{U}}\right)
$$


163 where $\lambda_{230 \mathrm{Th}}\left(=9.24 \times 10^{-6} \mathrm{y}^{-1}\right)$ and $\lambda_{238 \mathrm{U}}\left(1.55 \times 10^{-10} \mathrm{y}^{-1}\right)$ are the time constants for the radioactive 164 decay of ${ }^{230} \mathrm{Th}$ and ${ }^{238} \mathrm{U}$ and $\mathrm{m}_{230 \mathrm{Th}}$ and $\mathrm{m}_{238 \mathrm{U}}$ their molar masses (this calculation neglects ${ }^{235} \mathrm{U}$ whose 165 abundance is less that $1 \%$ ). The hypothesis of the secular equilibrium between ${ }^{230} \mathrm{Th}$ and ${ }^{238} \mathrm{U}$ is 166 necessary to use equation 1 and equation 2, although it is not always fulfilled in weathered lithogenic 167 detritus (Pham et al., 2005). Further work is needed to precisely constrain the average ${ }^{230} \mathrm{Th} /{ }^{238} \mathrm{U}$ ratio 168 of atmospheric aerosols particularly in areas dominated by these inputs.

169 The $U$ content of the trapped sample ranges from $0.24 \pm 0.25 \mathrm{ppm}$ to $2.02 \pm 0.06 \mathrm{ppm}$. The $\mathrm{U}$ 170 content in crustal rocks ranges from $1 \mathrm{ppm}$ (lower crust) to $2.8 \mathrm{ppm}$ (upper crust) and hence 171 atmospheric dust have variable U content (Taylor and McLennan, 1995). Organic matter is enriched

172 in $\mathrm{U}$ at ppm level, whereas pelagic carbonates are depleted in $\mathrm{U}(<0.1 \mathrm{ppm})$ (Anderson, 1982;

173 Henderson and O'Nions, 1995). Therefore, a significant fraction of the U present in the sample could 174 be authigenic $\mathrm{U}$ recently incorporated in organic matter. This authigenic $\mathrm{U}$ must not be taken into 175 account to evaluate the supported ${ }^{230} \mathrm{Th}$. Therefore, $\mathrm{U}_{\text {litho }}$ is bracketed with 2 extreme assumptions:

176 1) All the $U$ in the trapped material is lithogenic and no correction of authigenic contribution has to be 177 done $\left(\mathrm{U}_{\text {auth }}=0\right)$ :

$178 \quad \mathrm{U}_{\text {litho }}=\mathrm{U}_{\text {measured }}$

179 2) Some $U$ is lithogenic and an authigenic $U$ fraction is associated to organic matter (and to organic 180 matter only). To estimate the authigenic $\mathrm{U}$ concentration in organic matter, we normalise the total $\mathrm{U}$ 181 concentration and the lithogenic fraction by the fraction represented by the lithogenic and organic 182 material $\left(\mathrm{f}_{\text {litho }}+\mathrm{f}_{\mathrm{om}}\right)$ :

$183 \mathrm{U}_{\text {norm }}=\mathrm{U} /\left(\mathrm{f}_{\mathrm{litho}}+\mathrm{f}_{\mathrm{om}}\right)$

$184 \mathrm{f}_{\text {litho-norm }}=\mathrm{f}_{\text {litho }} /\left(\mathrm{f}_{\text {litho }}+\mathrm{f}_{\text {om }}\right)$ 
185 This normalisation removes the dilution effect of $\mathrm{U}$-poor phases (carbonates). In a diagram $\mathrm{U}_{\text {norm }}$

186 versus $\mathrm{f}_{\text {litho-norm }}$, the $\mathrm{U}_{\text {norm }}$ value for $\mathrm{f}_{\text {litho-norm }}=0$ gives $\mathrm{U}_{\mathrm{om}}$, the authigenic $\mathrm{U}$ concentration in the

187 organic matter (Fig. 2). It appears that $\mathrm{U}_{\mathrm{om}} \approx 0.5-1.5 \mathrm{ppm}$. To maximize the authigenic $\mathrm{U}$ correction,

188 we take $\mathrm{U}_{\mathrm{om}}=1.5 \mathrm{ppm}$. The authigenic $\mathrm{U}$ content of each sample is given by:

$189 \mathrm{U}_{\text {auth }}=\mathrm{U}_{\mathrm{om}} \times \mathrm{f}_{\mathrm{om}}$

190 With the 2 limiting cases, the mean $\mathrm{U}_{\text {litho }}$ and the range of uncertainty on the value are:

$191 \mathrm{U}_{\text {litho }}=\mathrm{U}_{\text {measured }}-\mathrm{U}_{\text {auth }} / 2 \pm\left(\mathrm{U}_{\text {auth }} / 2+\right.$ error on $\left.\mathrm{U}_{\text {measured }}\right)$

192 The $\mathrm{U}_{\text {measured }}$ value is the upper bound of this range. We note that the analytical uncertainty on $\mathrm{U}_{\text {measured }}$

193 is small compared to the uncertainty introduced by the 2 limiting cases. In future studies, the analysis

194 of the ${ }^{234} \mathrm{U} /{ }^{238} \mathrm{U}$ ratio could contribute to further constrain the nature of $\mathrm{U}$ in marine particles and 195 sediments.

$196 \quad \mathrm{The}^{230} \mathrm{Th}_{\mathrm{xs}}$ is then given by equation 2 . The ${ }^{230} \mathrm{Th}_{\mathrm{xs}}$ concentration ranges from $-0.6 \pm 1.8 \mathrm{pg} / \mathrm{g}$

197 to $19.1 \pm 2.4 \mathrm{pg} / \mathrm{g}$ at $200 \mathrm{~m}$ and from $2.8 \pm 2.1 \mathrm{pg} / \mathrm{g}$ to $21.3 \pm 2.6 \mathrm{pg} / \mathrm{g}$ at $1000 \mathrm{~m}$ (Tab. 1). The highest

$198{ }^{230} \mathrm{Th}_{\mathrm{xs}}$ concentrations are generally found in the deepest traps in summer whereas the ${ }^{230} \mathrm{Th}_{\mathrm{xs}}$ 199 concentrations are low in winter. On average, ${ }^{230} \mathrm{Th}_{\mathrm{xs}}$ represents $28 \%$ of the total ${ }^{230} \mathrm{Th}$ at $200 \mathrm{~m}$ and 200 between $35 \%$ of the total ${ }^{230} \mathrm{Th}$ at $1000 \mathrm{~m}$.

\section{4. Discussion}

203 4.1. Particle dynamics at the DYFAMED site

204 4.1.1. Temporal evolution and control of the particle flux

205 Despite its proximity to the continent, the DYFAMED site is considered as an "open ocean" 206 site because it is protected from direct inputs of coastal waters by the Ligurian current (Marty et al., 207 2002). The Saharan dusts reaching DYFAMED have travelled at least 1000 or $2000 \mathrm{~km}$ since they 
208 have left their desert sources. As a consequence, the lithogenic material found at the DYFAMED site

209 is characteristic of eolian material rather than of direct river inputs. Hence, the temporal variability of

210 the particle concentration and flux is due to local forcing rather than to advective inputs (Stemmann et

211 al., 2002). The vertical particule flux is influenced by the biological production (regulated by the

212 vertical inputs of nutrients), the atmospheric dust inputs of Saharan and European origin and winter

213 mixing (Miquel et al., 1994).

The fate of the atmospheric dusts deposited at DYFAMED deserves attention because it will

216 be used in the discussion in section 4.2.3. The deposition of Saharan dust over the Mediterranean Sea

217 occurs mostly in spring and summer although strong pulses may also occur in winter (Migon et al.,

218 2002). This general pattern can be compared with the total atmospheric deposition of Al recorded

219 from July 1999 to July 2000 at the Pirio site on the NW coast of Corsica (Loÿe-Pilot et al., 2001). This

220 site located $240 \mathrm{~km}$ SE of DYFAMED (Fig. 1) is free of local contamination and the atmospheric

221 fluxes recorded at Pirio are consistent with those collected on the French Riviera (Loÿe-Pilot et al.,

222 2001). Therefore, it represents a good recording of the Saharan dust deposition events that are

223 susceptible to have reached DYFAMED. At Pirio, strong Al deposition from July to October 1999

$224\left(1.25-9.24 \mathrm{mg} / \mathrm{m}^{2} / \mathrm{d}\right)$ and from Mid-April to July $2000\left(1.20-3.67 \mathrm{mg} / \mathrm{m}^{2} / \mathrm{d}\right)$, whereas very low fluxes

225 are recorded from November 1999 to Mid-April $2000\left(0.03-0.16 \mathrm{mg} / \mathrm{m}^{2} / \mathrm{d}\right)$ (Fig. 3). This lack of

226 Saharan events during this period was also observed over the same period at the La Castanya

227 Biological Station (NE Spain)), where no red rain event was recorded from November $15^{\text {th }} 1999$ to

228 March $25^{\text {th }} 2000$ (Avila et al., 2007).

229

The vertical Al flux recorded at DYFAMED at $200 \mathrm{~m}$ are clearly not synchronized with the

230 atmospheric deposition described above (Fig. 3). From July $15^{\text {th }} 1999$ to December $5^{\text {th }} 1999$, the Al 
231 flux trapped at $200 \mathrm{~m}$ is always lower than $1.5 \mathrm{mg} / \mathrm{m}^{2} / \mathrm{d}$, whereas from December $9^{\text {th }} 1999$ to June $25^{\text {th }}$ 2322000 , it ranges from $4.9 \mathrm{mg} / \mathrm{m}^{2} / \mathrm{d}$ to $16.9 \mathrm{mg} / \mathrm{m}^{2} / \mathrm{d}$.

233 In previous studies, the vertical transfer of marine particles at the DYFAMED site was 234 described as a three step seasonal transfer scenario (Migon et al., 2002; Sarthou and Jeandel, 2001; 235 Sicre et al., 1999; Ternois et al., 1996) that accounts for the observations presented above:

236 (i) In summer and autumn, during the period of water stratification, biological fluxes are low and do 237 not allow the transfer of lithogenic material down to $200 \mathrm{~m}$ depth. Atmospheric material accumulates 238 along the seasonal thermocline, while below the thermocline a series of physico-chemical processes 239 lead to the formation of small non-biogenic aggregates. During that period, the residence time of the 240 suspended particles is the surface water can exceed 200 days (Schmidt et al., 2002).

241 (ii) In winter, the disappearance of the thermocline (and the sinking of dense water when it occurs) is 242 responsible for a rapid downward transfer of the lithogenic matter accumulated in the surface layer.

243 (iii) In spring, the availability of nutrients brought to surface waters by the winter vertical mixing 244 allows phytoplankton blooms. The sinking of particulate matter (including atmospheric dust) is then 245 governed by biological activity and can be very fast (Buat-Ménard et al., 1989; Fowler et al., 1987; 246 Schmidt et al., 1992).

247 Due to the lack of sedimentation between the end of the summer bloom and the winter mixing, 248 the lithogenic rich particles collected at $200 \mathrm{~m}$ or $1000 \mathrm{~m}$ in winter have spent several (3-5) months 249 above and at the seasonal thermocline. This is less than the residence time estimated for the suspended 250 particles between the surface and $200 \mathrm{~m}$ or $1000 \mathrm{~m}$. At DYFAMED, the mean settling speed of the 251 small $(>0.2 \mu \mathrm{m})$ particle estimated by the ${ }^{230} \mathrm{Th}_{\mathrm{xS}}$ method is $\mathrm{S}=250 \mathrm{~m} / \mathrm{y}$ (Roy-Barman et al., 2002).

252 This settling speed of small particles is in the lower end of the range determined in the ocean. In the 253 oligotrophic Central North Pacific, the small particle settling speed is of $330 \mathrm{~m} / \mathrm{y}$ (Roy-Barman et al., 
254 1996) whereas in coastal areas the settling speed is of the order of $1000 \mathrm{~m} / \mathrm{y}$ (Huh and Beasley, 1987).

255 The estimate of the settling speed at DYFAMED (Roy-Barman et al., 2002) may not be very accurate

256 because it is based on a budget that depends more on the ventilation rate of the deep waters than on

257 the thorium scavenging rate. Therefore, we suspect that this value underestimates the true settling

258 speed. Hence, the mean settling time of the suspended particles is expected to be less than 1 year

259 between 0 and $200 \mathrm{~m}$ and of the order of 3 years between $200 \mathrm{~m}$ and $1000 \mathrm{~m}$.

260 The particles collected at $200 \mathrm{~m}$ or $1000 \mathrm{~m}$ are not simply surface-derived particles. Their

261 chemical composition is affected by the mineralization of organic compounds (Sempéré et al., 2000),

262 by the dissolution of inorganic elements (Arraes-Mescoff et al., 2001) and aggregation of suspended

263 particles (Roy-Barman et al., 2002, Coppola et al., 2006). Aggregation is best visible by the increase

264 of the ${ }^{230} \mathrm{Th}_{\mathrm{xs}}$ flux between $200 \mathrm{~m}\left(0.24 \pm 0.11 \mathrm{pg} / \mathrm{m}^{2} / \mathrm{y}\right)$ and $1000 \mathrm{~m}\left(0.56 \pm 0.07 \mathrm{pg} / \mathrm{m}^{2} / \mathrm{y}\right)$. It is likely

265 that this increase of ${ }^{230} \mathrm{Th}_{\mathrm{xs}}$ flux between $200 \mathrm{~m}$ and $1000 \mathrm{~m}$ is due to aggregation of suspended

266 particles that are enriched in in situ produced ${ }^{230} \mathrm{Th}$ due to their high specific surface and long

267 residence time in the water column rather than to direct adsorption of in situ produced ${ }^{230} \mathrm{Th}$ on

268 trapped particles (Roy-Barman et al., 2002).

\subsubsection{Sediment trap efficiency}

271 It is worth evaluating the collection efficiency of the trap because a low efficiency can modify

272 the chemical composition of the trapped material by, as an example, an under-sampling of the finest

273 particles (Roy-Barman et al., 2005). To cancel the short-term seasonal variations of the ${ }^{230} \mathrm{Th}_{\mathrm{xs}}$ flux

274 induced by the seasonal variations of the particle flux, the annually averaged ${ }^{230} \mathrm{Th}_{\mathrm{xs}}$ flux is considered

275 (Bacon et al., 1985). Assuming that ${ }^{230} \mathrm{Th}_{\mathrm{xs}}$ is transported vertically by the settling particles only, the

276 collection efficiency (E) is just the ratio between the flux of ${ }^{230} \mathrm{Th}_{\mathrm{xs}}$ collected by the trap during a full 
277 year $(\mathrm{F})$ and the quantity of ${ }^{230} \mathrm{Th}_{\mathrm{xs}}$ produced over the trap by radioactive decay of ${ }^{234} \mathrm{U}$ (Guieu et al., 278 2005):

279

$$
E=\frac{F}{P \times h}
$$

281 where $\mathrm{F}$ is the year-averaged ${ }^{230} \mathrm{Th}_{\mathrm{xs}}$ flux collected by the trap, $\mathrm{P}$ is the ${ }^{230} \mathrm{Th}$ production rate $(\mathrm{P}=0.65$

$282 \mathrm{fg} / \mathrm{l} / \mathrm{y}$ in the salty Mediterranean sea) and $\mathrm{h}$ is the trap depth. Under these assumptions, we obtain $\mathrm{E}=$ $283187 \pm 85 \%$ at $200 \mathrm{~m}$ and $\mathrm{E}=87 \pm 11 \%$ at $1000 \mathrm{~m}$.

Overall, the trapping efficiency is close to $100 \%$ considering the uncertainties and there is no 285 evidence of strong under-trapping. This high trapping efficiency can be related to the generally low 286 speed of the currents at $200 \mathrm{~m}$ and $1000 \mathrm{~m}$ at DYFAMED (Miquel and La Rosa, 2001; Roy-Barman et 287 al., 2002). This is the first published determination of the PPS5 trap efficiency at DYFAMED and it 288 validates the numerous sediment trap based studies at DYFAMED.

\subsection{Testing the potential carriers of ${ }^{230} T h_{x s}$}

291 In this section, we look at the correlations between the concentration of ${ }^{230} \mathrm{Th}_{\mathrm{xs}}$ and of different

292 phases constituting the particulate material. With this approach of comparing concentrations rather

293 than vertical fluxes, we try to determine the phases on which ${ }^{230} \mathrm{Th}_{\mathrm{xs}}$ is adsorbed but not necessarily

294 the ones that create the vertical flux through aggregation and ballasting. The parameters controlling

295 the partition coefficient $\mathrm{K}_{\mathrm{d} \_b u l k}{ }^{\text {Th }}$ between the bulk particulate and the dissolved phases are

296 controversial. Field-based estimate of $\mathrm{K}_{\mathrm{d}_{-} b u l k}{ }^{\mathrm{Th}}$ is obtained by dividing the amount of nuclides per $\mathrm{g}$ of

297 bulk trapped particles by the total amount of nuclides (dissolved+particulate) per ml of seawater in the

298 water through which the particle sunk.

299

$\mathrm{K}_{\mathrm{d} \_ \text {bulk }}{ }^{\mathrm{Th}}=\left[{ }^{230} \mathrm{Th}_{\mathrm{xs}}\right]_{\text {particulate matter }} /\left[\left[^{230} \mathrm{Th}_{\mathrm{xs}}\right]_{\text {seawater }}\right.$ 
300 And for the fractionation between a given phase of the particulate matter and seawater:

$$
\mathrm{K}_{\mathrm{d} \_ \text {phase }}{ }^{\text {Th }}=\mathrm{K}_{\mathrm{d} \_ \text {bulk }}{ }^{\text {Th }} /[\text { phase }]_{\text {particulate matter }}
$$

302 In the southern and Pacific oceans, the correlation between $\mathrm{K}_{\mathrm{d}_{\_} \text {bulk }}^{\text {Th }}$ and the carbonate content 303 of trapped particles suggests that ${ }^{230}$ Th scavenging is controlled by carbonates (Chase and Anderson, 304 2004; Chase et al., 2002; Chase et al., 2003). In regions with higher lithogenic content in the trapped 305 material, both carbonate and lithogenic material should scavenge ${ }^{230}$ Th (Chase et al., 2002; Narita et 306 al., 2003). Revisiting the same data set, Luo and $\mathrm{Ku}$ (2004) noted a strong correlation between $307 \mathrm{~K}_{\mathrm{d} \_ \text {bulk }}{ }^{\mathrm{Th}}$ and the lithogenic content of the trapped particles and proposed that ${ }^{230} \mathrm{Th}$ is scavenged 308 mainly by the lithogenic phase (Luo and $\mathrm{Ku}, 2004 \mathrm{a}$; Luo and $\mathrm{Ku}, 2004 \mathrm{~b}$ ). However, the $\mathrm{K}_{\mathrm{d} \_l i t h o}{ }^{\mathrm{Th}}$ $309\left(2.3 \times 10^{8} \mathrm{ml} / \mathrm{g}\right)$ obtained at these sites is more than one order of magnitude larger than those obtained 310 in regions with strong lithogenic inputs $\left(1 \times 10^{7} \mathrm{ml} / \mathrm{g}\right)$ (Chase et al., 2002). In the Arctic Ocean where 311 biological productivity is very low, ice-rafted lithogenic particles are proposed to scavenge ${ }^{230} \mathrm{Th}$ 312 (Edmonds et al., 1998; Trimble et al., 2004). In the Arabian Sea, the lack of consistency between $313 \mathrm{~K}_{\mathrm{d}_{\_} \text {bulk }}^{\text {Th }}$ and the major components of the sinking particles suggested that Th scavenging is not 314 controlled by major phases (Scholten et al., 2005). More recently, it was proposed that Mn oxides

315 rather than lithogenic particles or carbonates control ${ }^{230} \mathrm{Th}$ scavenging on marine particles (Roy316 Barman et al., 2005). This was based on (1) the strong correlation between Mn and ${ }^{230}$ Th content of 317 marine particles collected in the NE Atlantic Ocean and (2) the consistency of the $\mathrm{K}_{\mathrm{d} \_\mathrm{MnO} 2}{ }^{\mathrm{Th}}$ estimates 318 over a large range of oceanic environment. However, only a limited number of samples from area with 319 strong lithogenic inputs were available in this study and we now re-explore the possible relationships 320 between ${ }^{230} \mathrm{Th}_{\mathrm{xs}}$ and the different components of the DYFAMED trapped particles. 
323 The lack of correlation between $\mathrm{CaCO}_{3}$ and ${ }^{230} \mathrm{Th}_{\mathrm{xs}}$ (Fig. 4a) is consistent with the results 324 obtained in the NE Atlantic and in the Arabian Sea (Roy-Barman et al., 2005; Scholten et al., 2005). It

325 confirms that the linear correlation observed between $\mathrm{CaCO}_{3}$ and ${ }^{230} \mathrm{Th}_{\mathrm{xs}}$ in the Southern Ocean and in

326 the Equatorial Pacific (Chase et al., 2002) is not a general feature. This correlation may be due to the

327 fortuitous correlation of $\mathrm{CaCO}_{3}$ and ${ }^{230} \mathrm{Th}_{\mathrm{xs}}$ bearing phases, possibly $\mathrm{MnO}_{2}$ or lithogenic particles

328 (Roy-Barman et al., 2005).

329

The lack of correlation between Particulate Organic matter (estimated through POC

332 concentration) and ${ }^{230} \mathrm{Th}_{\mathrm{xs}}$ (Fig. 4b) is consistent with the results obtained in the NE Atlantic, in the

333 Southern Ocean, in the Equatorial Pacific and in the Arabian Sea (Chase et al., 2002; Roy-Barman et

334 al., 2005; Scholten et al., 2005). It suggests that in the deep ocean ${ }^{230} \mathrm{Th}$ is not scavenged significantly

335 by organic matter (Roy-Barman et al., 2005) contrary to what is probably the case in surface waters

336 (Coppola et al., 2002, Quigley et al., 2002).

\subsubsection{Lithogenic particles}

339 There is not a single correlation between ${ }^{230} \mathrm{Th}_{\mathrm{xs}}$ and ${ }^{232} \mathrm{Th}$ (Fig. 4c). This is not surprising 340 because ${ }^{230} \mathrm{Th}_{\mathrm{xs}}$ is scavenged from seawater, whereas ${ }^{232} \mathrm{Th}$ is mostly introduced in the ocean 341 imbedded in lithogenic particles (Adkins et al., 2006; Roy-Barman et al., 2002). This is reflected by

342 the high correlation between the ${ }^{232} \mathrm{Th}$ concentration and the $\mathrm{Al}$ concentration in the trapped material 343 (not shown, $\left.\mathrm{R}^{2}=0.98\right)$. Most samples define a gross linear relationship between ${ }^{230} \mathrm{Th}_{\mathrm{xs}}$ and ${ }^{232} \mathrm{Th}(200$ 
$344 \mathrm{~m}: \mathrm{R}^{2}=0.87$ and $\left.1000 \mathrm{~m}: \mathrm{R}^{2}=0.75\right)$. Lithogenic-rich samples collected during winter (and early

345 spring) do not fall on the main trend (circles with a cross inside in Fig. 4).

346 A double correlation between ${ }^{230} \mathrm{Th}_{\mathrm{xs}}$ and ${ }^{232} \mathrm{Th}$ was also obtained during the POMME

347 experiment in the North Atlantic (Roy-Barman et al., 2005). The main correlation was explained by a

348 mixture between small suspensions (enriched in ${ }^{230} \mathrm{Th}$ ) and lithogenic particles, whereas winter

349 samples with high ${ }^{232} \mathrm{Th}$ content and low ${ }^{230} \mathrm{Th}_{\mathrm{xs}}$ where due to a rapid transfer at depth of atmospheric

350 dust deposited at the sea surface (within 2 weeks at $400 \mathrm{~m}$ and the week after at $1000 \mathrm{~m}$ ). This rapid

351 transfer may have been due to incorporation of the dusts in faecal pellets or in marine snow.

352 Therefore, it was not possible to determine if these samples where not enriched in ${ }^{230} \mathrm{Th}_{\mathrm{xs}}$ because the

$353 \mathrm{~K}_{\mathrm{d} \_ \text {litho }}{ }^{\mathrm{Th}}$ is low or because ${ }^{230} \mathrm{Th}_{\mathrm{xs}}$ had not enough time to equilibrate with the newly arrived lithogenic

354 particles and seawater.

355 The DYFAMED site offers the opportunity to tackle this question. As explained in section

356 4.1.1., the lithogenic particles deposited in summer and autumn are not transferred directly through

357 the thermocline but rather stored at the top of the thermocline (during 3-5 months) until winter

358 convection allow them to cross the thermocline. Then, it takes 2 additional months for the lithogenic

359 particles to go from $200 \mathrm{~m}$ to $1000 \mathrm{~m}$ as indicated by the time lag of the Al flux between $200 \mathrm{~m}$ and

$3601000 \mathrm{~m}$ (Fig. 3). Despite this longer equilibration time between the lithogenic particles and seawater

361 compared to the POMME data, the lithogenic rich samples plot below the main ${ }^{230} \mathrm{Th}_{\mathrm{xs}}-$ lithogenic

362 fraction correlation at both $200 \mathrm{~m}$ and $1000 \mathrm{~m}$. The transit time of these particles is not as long as the

363 average residence time of the bulk suspended particles in the water column (see section 4.1.1.). So it is

364 possible that there was not enough time for ${ }^{230} \mathrm{Th}_{\mathrm{xs}}$ to reach complete equilibration between the winter

365 lithogenic particles and seawater. However, in the North Atlantic, the particles transporting a Saharan

366 dust pulse at $1000 \mathrm{~m}$ within 3 weeks have a larger $\mathrm{K}_{\mathrm{d} \_l i t h o}{ }^{\text {Th }}$ than particles transporting a Saharan dust

367 pulse in several months at $1000 \mathrm{~m}$ at DYFAMED. It suggests that the kinetic of ${ }^{230}$ Th adsorption on 
368 lithogenic particles is not the limiting factor of the ${ }^{230} \mathrm{Th}$ uptake by sinking particles. This is also 369 consistent with in vitro experiments indicating a fast sorption of ${ }^{230} \mathrm{Th}$ on lithogenic particles (Geibert 370 and Usbeck, 2004). Nevertheless, deposition of larger dust particles at DYFAMED compared to the 371 North Atlantic could explain the lower affinity of ${ }^{230} \mathrm{Th}$ for DYFAMED particles due to their lower 372 surface to volume ratio. Alternatively, it was proposed that the ${ }^{230} \mathrm{Th}_{\mathrm{xS}}$ content of trapped particles is 373 controlled by the incorporation of ${ }^{230} \mathrm{Th}_{\mathrm{xs}}$-rich, Ba-rich and Mn-rich suspended particles to the rapidly 374 sinking particles (Huang and Conte, 2009; Roy-Barman et al., 2005). This mixing would then control 375 the apparent $\mathrm{K}_{\mathrm{d} \_ \text {litho }}{ }^{\text {Th }}$ of the trapped particles. The low Ba content of lithogenic-rich winter samples 376 indicate a low contribution of the small suspended particle pool (Barite tend to accumulate in this 377 small particle pool (Sternberg et al., 2007)) despite high lithogenic content. In any case, the 378 DYFAMED results confirm that arrival of atmospheric pulses of Saharan material decreases the 379 degree of correlation between the ${ }^{230} \mathrm{Th}_{\mathrm{xs}}$ and $\mathrm{f}_{\text {litho }}$ for the whole dataset.

380 Assuming that all the ${ }^{230} \mathrm{Th}_{\mathrm{xs}}$ is adsorbed on the lithogenic material and that there is a chemical 381 equilibration of ${ }^{230} \mathrm{Th}_{\mathrm{xs}}$ between lithogenic particles and seawater, we can estimate $\mathrm{K}_{\mathrm{d} \_ \text {litho }}{ }^{\mathrm{Th}}$ with the 382 trapped particles analyzed in the present work and seawater data (Roy-Barman et al., 2002). We focus 383 on the $1000 \mathrm{~m}$ samples, because their ${ }^{230} \mathrm{Th}_{\mathrm{xs}}$ is less sensitive to uncertainties on lithogenic correction 384 and because there is some concern that at shallower depth the equilibration between seawater and 385 particulate matter is not achieved (Chase et al., 2002). We obtain $K_{d \_l i t h o}{ }^{T h}=(0.7 \pm 0.2) \times 10^{7}$ for the 386 main trend samples and $\mathrm{K}_{\mathrm{d} \_l i t h o}{ }^{\mathrm{Th}}(0.36 \pm 0.04) \times 10^{7}$ for the winter samples (Tab. 2). These values are 387 consistent with the result of $\mathrm{K}_{\mathrm{d} \_l i t h o}{ }^{\text {Th }} \approx 10^{7}$ obtained by (Chase et al., 2002) based on Atlantic samples 388 and much lower than the value $\mathrm{K}_{\mathrm{d} \_ \text {litho }}{ }^{\text {Th }} \approx 23 \times 10^{7}$ estimated by (Luo and $\mathrm{Ku}, 2004 \mathrm{a}$ ) based on sample 389 collected in area experiencing very low eolian inputs. 


\subsubsection{Mn oxides}

The relationship between ${ }^{230} \mathrm{Th}_{\mathrm{xs}}$ and $\mathrm{Mn}$ is quite similar to the relationship between ${ }^{230} \mathrm{Th}_{\mathrm{xs}}$ and the lithogenic fraction (Fig. 4c,e): excluding the winter samples, good correlations are obtained

394 between ${ }^{230} \mathrm{Th}_{\mathrm{xs}}$ and $\mathrm{Mn}\left(200 \mathrm{~m}: \mathrm{R}^{2}=0.83\right.$ and $\left.1000 \mathrm{~m}: \mathrm{R}^{2}=0.86\right)$. In the NE Atlantic, the lithogenic

395 content of the trapped particle was low enough $(<10 \%)$ so that the lithogenic contribution to the total

396 Mn was generally less than $50 \%$ and a good correlation was found between ${ }^{230} \mathrm{Th}_{\mathrm{xs}}$ and $\mathrm{Mn}$ (Roy-

397 Barman et al., 2005). The winter samples are still not on the main trend on a ${ }^{230} \mathrm{Th}_{\mathrm{xs}}$ and $\mathrm{Mn}_{\text {auth }}$

398 diagram (fig 4f) and excluding the winter samples, the goodness of fit of the ${ }^{230} \mathrm{Th}_{\mathrm{xs}}$ versus $\mathrm{Mn}_{\text {auth }}$ data

399 (200 m: $\mathrm{R}^{2}=0.56$ and $1000 \mathrm{~m}: \mathrm{R}^{2}=0.69$ ) is not as good as the ${ }^{230} \mathrm{Th}_{\mathrm{xs}}$ and Mn correlation. However,

400 correcting the DYFAMED samples for the lithogenic Mn contribution requires caution because the

$401 \mathrm{Mn} / \mathrm{Al}$ ratio of the insoluble fraction of Saharan dusts $(8.5 \pm 0.5) \times 10^{-3} \mathrm{~g} / \mathrm{g}$ is variable (Avila et al., 402 2007). In addition, the Mn/Al ratio of the "Saharan aerosols" collected in "clean" sites of Corsica or of 403 the French Riviera $\left(\mathrm{Mn} / \mathrm{Al}=16 \times 10^{-3}-38 \times 10^{-3}\right)$ can be 3-4 times higher indicating the contribution of 404 an anthropogenic Mn source (possibly European aerosols) (Ridame et al., 1999). Finally, Mn 405 dissolution can occur when it enters seawater (Guieu et al., 1994) or during particulate organic matter 406 mineralization (Arraes-Mescoff et al., 2001).

The $\mathrm{Mn} / \mathrm{Al}$ ratio of the DYFAMED samples range from $5 \times 10^{-3}$ to $16 \times 10^{-3}$ (average: $12.0 \times 10^{-3}$ ) 408 at $200 \mathrm{~m}$ and from $11 \times 10^{-3}$ to $18 \times 10^{-3}$ (average: $13.4 \times 10^{-3}$ ) at $1000 \mathrm{~m}$. These values are within the 409 range of the crustal rock average and at the low end of the atmospheric inputs range so that it is 410 difficult to correct for the "non authigenic" Mn fraction. The maximum of anthropogenic inputs 411 occurs at the end of summer (before winter mixing) and the end of winter (during winter mixing) 412 (Migon et al., 2008). Therefore, we cannot rule out that the Mn-rich and ${ }^{230} \mathrm{Th}_{\mathrm{xs}}$-poor winter samples 
413 fall out of the main correlation because the $\mathrm{Mn} / \mathrm{Al}$ ratio of their dusts is larger than the value used to 414 calculate $\mathrm{Mn}_{\text {auth }}$.

415 In surface waters, photoreduction limits the formation of Mn oxides, so that particulate Mn is 416 associated with organic matter (Johnson et al., 1996). Below the photic zone, Mn oxides are 417 precipitated on marine particles throughout the water column (Huang and Conte, 2009; Johnson et al., 418 1996). Assuming that all the ${ }^{230} \mathrm{Th}_{\mathrm{xs}}$ is adsorbed on these authigenic $\mathrm{Mn}$ oxides and that there is a 419 chemical equilibration of ${ }^{230} \mathrm{Th}_{\mathrm{xs}}$ between these oxides and seawater, we can estimate $\mathrm{K}_{\mathrm{d} \_\mathrm{MnO2}}{ }^{\mathrm{Th}}$. Still 420 focussing on the $1000 \mathrm{~m}$ samples, we obtain $\mathrm{K}_{\mathrm{d} \_\mathrm{MnO} 2}{ }^{\mathrm{Th}}=(1.1 \pm 0.4) \times 10^{10}$ for the main trend samples 421 and $\mathrm{K}_{\mathrm{d} \_\mathrm{MnO} 2}{ }^{\mathrm{Th}}=(0.6 \pm 0.1) \times 10^{10}$ for the winter samples $(\mathrm{Tab} .2)$. These values are lower but grossly 422 consistent with the result of $\mathrm{K}_{\mathrm{d} \_\mathrm{MnO} 2}{ }^{\mathrm{Th}} \approx 2 \times 10^{10}$ obtained for the Atlantic Ocean (Roy-Barman et al., 423 2005) and $\mathrm{K}_{\mathrm{d} \_\mathrm{MnO} 2}{ }^{\mathrm{Th}} \approx 3.5 \times 10^{10}$ estimated from sample collected in area experiencing very low eolian 424 inputs (Luo and Ku, 1999; Roy-Barman et al., 2002). In the previous section and in the present one, we successively assumed that all the ${ }^{230} \mathrm{Th}_{\mathrm{xs}}$ is 426 carried by the lithogenic particles or by the authigenic Mn oxides. We now try to choose between 427 these 2 hypotheses. It is well established that the slope of the correlation between the ${ }^{230} \mathrm{Th}_{\mathrm{xs}}$ 428 concentration and the lithogenic fraction of trapped particles is site-dependent (Chase and Anderson, 429 2004; Chase et al., 2002; Luo and Ku, 2004a; Luo and Ku, 2004b; Roy-Barman et al., 2005). Much of 430 the controversy on affinity of ${ }^{230} \mathrm{Th}_{\mathrm{xs}}$ for lithogenic particles resides in the interpretation of this site431 dependent slope that may reflect (1) true variations of $\mathrm{K}_{\mathrm{d}_{-} \text {litho }}{ }^{\text {Th }}$ from one site to the other depending on 432 the chemical and size characteristics of the lithogenic particles (Luo and $\mathrm{Ku}, 2004 \mathrm{a}$; Luo and $\mathrm{Ku}$, 433 2004b) or (2) more or less fortuitous correlation between the lithogenic fraction and another phase by 434 which the ${ }^{230} \mathrm{Th}_{\mathrm{xs}}$ is effectively taken up such as carbonates (Chase and Anderson, 2004; Chase et al., 435 2002) or Mn oxides (Roy-Barman et al., 2005). The present study does not allow choosing clearly 
436 between the 2 hypotheses because the $\mathrm{Mn}$ concentration and the lithogenic fraction are strongly 437 correlated $\left(\mathrm{R}^{2}=0.92\right)$. However, we note that if neither $\mathrm{K}_{\mathrm{d} \_l i t h o}{ }^{\text {Th }}$ nor $\mathrm{K}_{\mathrm{d} \_\mathrm{MnO} 2}{ }^{\text {Th }}$ are constant between

438 high dust and low dust sites, $\mathrm{K}_{\mathrm{d} \_\mathrm{MnO} 2}{ }^{\text {Th }}$ estimated from sediment trap data varies by at most a factor 7 , 439 whereas $\mathrm{K}_{\mathrm{d} \_l i t h o}{ }^{\mathrm{Th}}$ varies by a factor 50 (Tab. 2 ). Thus the affinity of ${ }^{230} \mathrm{Th}_{\mathrm{xs}}$ for Mn oxides appears to 440 be much less "site-dependent" than its affinity for lithogenic particles, suggesting a stronger link 441 between ${ }^{230} \mathrm{Th}_{\mathrm{xs}}$ scavenging and authigenic $\mathrm{MnO}_{2}$ precipitation than with lithogenic particles. In that 442 case lithogenic matter may serve as support for Mn oxide precipitation and then as ballast for its 443 transport.

444 These results combined with the lack of correlation found between the ${ }^{230} \mathrm{Th}_{\mathrm{xs}}$ concentration 445 and the $\mathrm{CaCO}_{3}$ content of trapped particles at DYFAMED as well as in previous studies (Roy-Barman 446 et al., 2005; Scholten et al., 2005), suggests that the high $\mathrm{K}_{\mathrm{d}_{-} \mathrm{CaCO} 3}{ }^{\text {Th }}$ used in various modelling studies 447 (Dutay et al., 2009; Siddall et al., 2005) should be re-evaluated and that Mn coatings have to be taken 448 into account in these models. The correlation between ${ }^{230} \mathrm{Th}_{\mathrm{xs}}$ and carbonates at some sites could be 449 explained if carbonates are substrates for Mn oxide precipitation (Martin and Knauer, 1983).

\section{Conclusion}

The present study brings a new insight on thorium scavenging in regions with strong lithogenic

455 inputs. The lack of correlation between ${ }^{230} \mathrm{Th}_{\mathrm{xs}}$ and the carbonate and organic matter fractions suggests 456 that carbonates and organic matter are not the main phases carrying the in situ ${ }^{230} \mathrm{Th}$ in the 457 Mediterranean Sea. The high temporal resolution of DYFAMED sediment trap time series indicates 458 that different correlations exist between ${ }^{230} \mathrm{Th}_{\mathrm{xs}}$ concentration and the lithogenic fraction of the 459 trapped particles. Most samples define a correlation between ${ }^{230} \mathrm{Th}_{\mathrm{xs}}$ and the lithogenic fraction but 460 lithogenic-rich and ${ }^{230} \mathrm{Th}_{\mathrm{xs}}$ - poor particle pulses occur in winter. Assuming that ${ }^{230} \mathrm{Th}_{\mathrm{xs}}$ is only carried 
461 by lithogenic particles, the estimated value of $\mathrm{K}_{\mathrm{d} \_ \text {litho }}{ }^{\text {Th }}$ range from $(0.42 \pm 0.04) \times 10^{7} \mathrm{ml} / \mathrm{g}$ to $(0.8 \pm$ $4620.2) \times 10^{7} \mathrm{ml} / \mathrm{g}$. Similarly, a correlation between the ${ }^{230} \mathrm{Th}_{\mathrm{xs}}$ concentration and the Mn concentrations 463 occurs with also Mn-rich and ${ }^{230} \mathrm{Th}_{\mathrm{xs}}$ - poor particle pulses in winter. Assuming that ${ }^{230} \mathrm{Th}_{\mathrm{xs}}$ is only 464 carried by authigenic $\mathrm{MnO}_{2}$ precipitates, the estimated value of $\mathrm{K}_{\mathrm{d} \_\mathrm{MnO} 2}{ }^{\text {Th }}$ ranges from $(0.6 \pm 0.1) \times$ $46510^{10} \mathrm{ml} / \mathrm{g}$ to $(1.1 \pm 0.4) \times 10^{10} \mathrm{ml} / \mathrm{g}$. Comparing $\mathrm{K}_{\mathrm{d}}^{\mathrm{Th}}$ obtained at different sites indicates that the range 466 of variation of $\mathrm{K}_{\mathrm{d} \_\mathrm{MnO} 2}{ }^{\mathrm{Th}}$ is significantly lower than the range of variation $\mathrm{K}_{\mathrm{d} \_ \text {litho }}{ }^{\mathrm{Th}}$, suggesting that $467{ }^{230} \mathrm{Th}_{\mathrm{xs}}$ has a tighter link with $\mathrm{MnO}_{2}$ rather than with lithogenic particles and that hence $\mathrm{MnO}_{2}$ is a 468 more likely carrier of ${ }^{230} \mathrm{Th}_{\mathrm{xs}}$ than lithogenic particles. The unambiguous determination of the particles 469 carrying thorium isotopes remains to be done. 


\section{Acknowledgments}

475 We warmly thank J.-C. Marty, PI of the DYFAMED program until 2007, for his support. We are 476 grateful to R. Freydier for his help with the Neptune utilization and to F. Candaudap for his help with 477 the Elan 6000 utilization. Discussions with M.-A. Sicre, C. Guieu and L. Coppola helped us to clarify

478 our ideas about particle dynamics at DYFAMED. The thoughtful comments of W. Geibert, S. Luo and 479 of an anonymous reviewer profoundly improved the article. The DYFAMED Program was supported 480 by the French agencies CNRS/ INSU (PROOF-PATOM). The International Atomic Energy Agency is 481 grateful for the support provided to its Marine Environment Laboratories by the Government of the 482 Principality of Monaco.This is LSCE contribution number LSCE 3906.

483

484

485

486

487 


\section{Figure Captions}

490 Figure 1: The DYFAMED station, in the western Mediterranean (from Ocean Data View)

492 Figure 2: $\mathrm{U}_{\text {norm }}$ versus $\mathrm{f}_{\text {litho_norm. }}$ See text for definitions. The straight lines represent mixing lines 493 between hypothetical (lithogenic free) organic matter end members and lithogenic end members. It 494 suggests that the organic matter end-member contains at most $1.5 \mathrm{ppm}$ of authigenic U. Crustal end495 member from (Taylor and McLennan, 1995).

Figure 3: Temporal evolution of the trapped material at $200 \mathrm{~m}$ and $1000 \mathrm{~m}$ and atmospheric deposit at 498 Pirio in Corsica. A: Mass flux. B: Al flux.

500 Figure 4: ${ }^{230} \mathrm{Th}_{\mathrm{xs}}$ as a function of the particle composition. a: ${ }^{230} \mathrm{Th}_{\mathrm{xs}}$ versus $\mathrm{CaCO}_{3}$. b: ${ }^{230} \mathrm{Th}_{\mathrm{xs}}$ versus 501 organic matter. c: ${ }^{230} \mathrm{Th}_{\mathrm{xs}}$ versus lithogenic matter d: ${ }^{230} \mathrm{Th}_{\mathrm{xs}}$ versus $\mathrm{Ba}_{\mathrm{xs}} . \mathrm{e}:{ }^{230} \mathrm{Th}_{\mathrm{xs}}$ versus $\mathrm{Mn}_{\text {total. }} \mathrm{f}$ : $502{ }^{230} \mathrm{Th}_{\mathrm{xs}}$ versus $\mathrm{Mn}_{\text {auth. }}$. Large error bars on the lithogenic fraction, $\mathrm{Ba}_{\mathrm{xs}}$ and $\mathrm{Mn}_{\mathrm{auth}}$ are due to the 503 variability of the composition of the insoluble fraction of Saharan aerosols (Avila et al., 2007). 


\section{References}

512

513 Adkins J., deMenocal P., and Eshel G., 2006. The “African humid period”' and the record of marine

514 upwelling from excess 230Th in Ocean Drilling Program Hole 658C. Paleocanogr. 21, 515 doi:10.1029/2005PA001200.

516 Anderson R. F., 1982. Concentration, vertical flux, and remineralisation of particulate uranium in 517 seawater. Geochim. Cosmochim. Acta 46, 1293-1299.

518 Anderson, R. F., Bacon, M. P. and Brewer P. G., 1983. Removal of ${ }^{231} \mathrm{~Pa}$ and ${ }^{230} \mathrm{Th}$ at ocean margins, $519 \quad$ Earth Planet. Sci. Lett. 66, 73-90.

520 Anderson R. F., Lao Y., Broecker W. S., Trumore S. E., Hofmann H. J., and Wolfli W., 1990.

521 Boundary scavenging in the Pacific Ocean: a comparison of ${ }^{10} \mathrm{Be}$ and ${ }^{231} \mathrm{~Pa}$. Earth Planet. Sci.

$522 \quad$ Lett. $96,287-304$.

523 Andersson P. S., Wasserburg G. J., Chen J. H., Papanastassiou D. A., and Ingri J., 1995. ${ }^{238} \mathrm{U}_{-}{ }^{234} \mathrm{U}^{\text {and }}$

$524 \quad{ }^{232} \mathrm{Th}^{230} \mathrm{Th}$ in the Baltic sea and in river water. Earth Planet. Sci. Lett. 130, 217-234.

525 Arraes-Mescoff R., Coppola L., Roy-Barman M., Souhaut M., Tachikawa K., Jeandel C., Sempéré R.,

526 and Yoro $\mathrm{C} .$, 2001. The behavior of $\mathrm{Al}, \mathrm{Mn}, \mathrm{Ba}, \mathrm{Sr}, \mathrm{REE}$ and $\mathrm{Th}$ isotopes during in vitro 527 bacterial degradation of large marine particles. Mar. Chem. 73, 1-19.

528 Avila A., Alarcon M., Castillo S., Escudero M., Garcia Orellana J., Masque P., and Querol X., 2007.

529 Variation of soluble and insoluble calcium in red rains related to dust sources and transport 530 patterns from North Africa to northeastern Spain. J. Geophys. Res. 112, $531 \quad$ doi:10.1029/2006JD007153.

532 Bacon M. P. and Anderson R. F., 1982. Distribution of thorium isotopes between dissolved and 533 particulate forms in the Deep-Sea. J. Geophys. Res. 87, 2045-2056. 
534 Bacon M. P., Huh C.-H., Fleer A. P., and Deuser W. G., 1985. Seasonality in the flux of natural 535 radionuclides and plutonium in the deep Sargasso Sea. Deep-Sea Res. 32, 273-286.

536 Banner J. L., Wasserburg G. J., Chen J. H., and Moore C. H., 1990. ${ }^{234} \mathrm{U}_{-}{ }^{238} \mathrm{U}_{-}{ }^{230} \mathrm{Th}^{-232}$ Th systematics 537 in saline groundwaters from central Missouri. Earth Planet. Sci. Lett. 101, 296-312.

538 Buat-Ménard P., Davies J., Remoudaki E., Miquel J. C., Bergametti G., Lambert C. E., Ezat U., 539 Quetel C., La Rosa J., and Fowler S. W., 1989. Non steady state removal of atmospheric particles 540 from Mediterranean surface waters. Nature 340, 131-134.

541 Buesseler K. O., Antia A. N., Chen M., Fowler S. W., Gardner W. D., Gustaffson Ö., Harada K., 542 Michaels A. F., Rutgers van der Loeff M., Sarin M., Steinberg D. K., and Trull T., 2007. An 543 assessment of the use of sediment traps for estimating upper ocean particle fluxes. J. Mar. Res. $544 \quad 65,345-416$.

545 Buesseler K. O., Bacon M., Cochran J. K., and Livingston H. D., 1992. Carbon and nitrogen export 546 during the JGOFS North Atlantic Bloom Experiment estimated from ${ }^{234} \mathrm{Th}:{ }^{238} \mathrm{U}$ desiquilibria. $547 \quad$ Deep Sea Res. 39, 1115-1137.

548 Chase Z. and Anderson R. F., 2004. Comment on "On the importance of opal, carbonate, and 549 lithogenic clays in scavenging and fractionating ${ }^{230} \mathrm{Th},{ }^{231} \mathrm{~Pa}$ and ${ }^{10} \mathrm{Be}$ in the ocean"' by S. Luo 550 and T.-L. Ku. Earth Planet. Sci. Lett. 220, 213-222.

551 Chase Z., Anderson R. F., Fleisher M. Q., and Kubik P. W., 2002. The influence of particle 552 composition and particle flux on scavenging of Th, $\mathrm{Pa}$ and $\mathrm{Be}$ in the ocean. Earth Planet. Sci 553 Lett. 204, 215-229.

554 Chase Z., Anderson R. F., Fleisher M. Q., and Kubik P. W., 2003. Scavenging of ${ }^{230} \mathrm{Th},{ }^{231} \mathrm{~Pa}$ and ${ }^{10} \mathrm{Be}$ 555 in the Southern Ocean(SW Pacific sector): the importance of particle flux, particle composition 556 and advection. Deep-Sea Res. II 50, 739-768. 
557 Coppola, L., Roy-Barman, M., Mulsow, S., Povinec, P. and Jeandel, C., 2006. Thorium isotopes as 558 tracers of particles dynamics and deep water circulation in the Indian sector of the Southern Ocean (ANTARES IV). Mar. Chem. 100, 299-313.

560 Coppola, L., Roy-Barman, M., Wassmann, P. and Jeandel, C., 2002. Calibration of sediment traps and 561 particulate organic carbon export using 234Th in the Barents Sea. Mar. Chem. 80, 11-26.

562 Dutay J.-C., Lacan F., Roy-Barman M., and Bopp L., 2009. Study of the influence of the particles' 563 size and type on the simulation of ${ }^{231} \mathrm{~Pa}$ and ${ }^{230} \mathrm{Th}$ with a global coupled biogeochemical- ocean 564 general circulation model: a first approach. G3 10, doi:10.1029/2008GC002291.

565 Edmonds H. N., Moran S. B., Hoff J. A., Smith J. N., and Edwards R. L., 1998. Protactinium-231 and 566 Thorium-230 abundances and high scavenging rates in the Western Arctic Ocean. Science 280, $567 \quad 405-407$.

568 Fowler S. W., Buat-Ménard P., Yokohama Y., Ballestra S., Holm E., and Van Nguyen H. V., 1987. 569 Rapid removal of Chernobyl fallout from Mediterranean surface waters by biological activity. $570 \quad$ Nature 329, 56-58.

571 Francois R., Frank M., Rutgers van der Loeff M. M., and Bacon M. P., 2004. 230Th normalization: 572 An essential tool for interpreting sedimentary fluxes during the late Quaternary. 573 Paleoceanography 19, PA1018, doi:10.1029/2003PA000939,.

574 Geibert W. and Usbeck R., 2004. Adsorption of thorium and protactinium onto different particle 575 types: Experimental findings. Geochim. Cosmochim. Acta 68, 1489-1501.

576 Guieu C., Duce R. A., and Arimoto R., 1994. Dissolved input of Manganese in the ocean: the aerosol 577 source. J. Geophys. Res. 99, 18789-18800.

578 Guieu C., Roy-Barman M., Leblond N., Jeandel C., Souhaut M., Le Cann B., Dufour A., and Bournot 579 C., 2005. Vertical particle flux in the North-East Atlantic Ocean (POMME experiment). J. $580 \quad$ Geophys. Res. 110., doi:10.1029/2004JC002672. 
581 Henderson G. and O'Nions R. K., 1995. 234U/238U ratios in quaternary planctonic foraminifera. 582 Geochim. Cosmochim. Acta. 56(4685-4694).

583 Huang S. and Conte M. H., 2009. Source/process apportionment of major and trace elements in 584 sinking particles in the Sargasso sea. Geochim. Cosmochim. Acta 73, 65-90.

585 Huh C.-A. and Beasley T. M., 1987. Profiles of dissolved and particulate thorium isotopes in the 586 water column of coastal Southern California. Earth Planet. Sci. Lett. 85, 1-10.

587 Johnson K. S., Coale K. H., Berelson W. M., and Gordon R. M., 1996. On the formation of the 588 manganese maximum in the oxygen minimum. Geochim. Cosmochim. Acta 60(8), 1291-1299.

589 Klaas C. and Archer D. E., 2002. Association of sinking organic matter with various types of mineral 590 ballast in the deep sea: Implications for the rain ratio. Global Biogeochem. Cycles. 16, Art. No. $591 \quad 1116$.

592 Kuss J. and Kremling K., 1999. Particulate trace element fluxes in the deep northeast Atlantic Ocean, 593 Deep-Sea Res. I 46, 1377- 1403.

594 Loÿe-Pilot M. D., Guieu C., and Ridame C. (2001) Atmospheric bulk fluxes of natural and polluant 595 metals to the North Western Mediteranean: Their trend over the last 15 years (1985-2000). In 596 UNEP/MAP/MEDPOL: Atmospheric Transport and Deposition of Pollutants into the Mediterranean Sea: Final Reports on Research Projects. MAP Technical Reports Series No. 133, $598 \quad$ UNEP/MAP, Athens, 2001.

599 Luo S. and Ku T.-L., 1999. Oceanic ${ }^{231} \mathrm{~Pa} /{ }^{230} \mathrm{Th}$ ratio influenced by particle composition and 600 remineralisation. Eath Planet. Sci. Lett. 167, 183-195.

601 Luo S. and Ku T.-L., 2004a. On the importance of opal, carbonate and lithogenic clays in scavenging 602 and fractionating ${ }^{230} \mathrm{Th},{ }^{231} \mathrm{~Pa}$ and ${ }^{10} \mathrm{Be}$ in the ocean,. Earth Planet. Sci. Lett. 220, 201-211. 
603 Luo S. and Ku T.-L., 2004b. Reply to Comment on "On the importance of opal, carbonate, and 604 lithogenic clays in scavenging and fractionating ${ }^{230} \mathrm{Th},{ }^{231} \mathrm{~Pa}$ and ${ }^{10} \mathrm{Be}$ in the ocean"'. Earth 605 Planet. Sci. Lett. 220, 223-229.

606 Martin J. H. and Knauer G. A., 1983. Vertex: Manganese transport with CaCO3. Deep-Sea Res. 30, $607 \quad 411-425$

608 Marty J. C., Chiaverini J., Pizay M. D., and Avril B., 2002. Seasonal and interannual dynamics of 609 nutrients and phytoplankton pigments in the western Mediterranean Sea at the DYFAMED time610 series station (1991-1999). Deep Sea Res. II 49, 1965-1985.

611 Migon C., Robin T., Dufour A., and Gentili B., 2008. Decrease of lead concentrations in the Western 612 Mediterranean atmosphere during the last 20 years. Atmospheric Environment 42, 815-821.

613 Migon C., Sandroni V., Marty J.-C., Gasser B., and Miquel J.-C., 2002. Transfer of atmospheric 614 matter through the euphotic layer in the northwestern Mediterranean: seasonal pattern and 615 driving forces. Deep-Sea Res. II 49, 2125-2141.

616 Miquel J. C., Buat-Ménard P., Fowler S. W., and La Rosa J., 1994. Dynamics of the downward flux of 617 particles and carbon in the open northwestern Mediterranean Sea. Deep Sea Res. 41, 243-261.

618 Miquel J. C. and La Rosa J., 2001. Suivi à long terme des flux particulaires au site DYFAMED (Mer 619 Ligure, Méditerranée Occidentale). Océanis 25, 303-318.

620 Narita H., Abe R., Tate K., Kim Y., Harada K., and Tsunogai S., 2003. Anomalous large scavenging 621 of ${ }^{230} \mathrm{Th}$ and ${ }^{231} \mathrm{~Pa}$ controlled by particle composition in the northwestern North Pacific. J. 622 Oceanogr. 59(739-750).

623 Pham M. K., La Rosa J. J., Lee S. H., Oregioni B., and Povinec P. P., ., 2005. Deposition of Saharan 624 dust in Monaco rain 2001-2002: Radionuclides and elemental composition. Physica Scripta 118, $625 \quad 14-17$. 
626 Quigley M. S., Santschi P. H., Hung C. C., Guo L. D., and Honeyman B. D., 2002. Importance of acid 627 polysaccharides for Th-234 complexation to marine organic matter. Limnol. Oceanogr. 47, 367$628 \quad 377$.

629 Ridame C., Guieu C., and Loye-Pilot M. D., 1999. Trend in total atmospheric deposition fluxes of 630 aluminium, iron and trace metals in the North western Mediterranean, over the past decade 631 (1985-1997). J. Geophys. Res. 104, 127-138.

632 Roy-Barman M., Chen J. H., and Wasserburg G. J., $1996 .{ }^{230} \mathrm{Th}^{232} \mathrm{Th}$ systematics in the Central 633 Pacific Ocean: the sources and the fates of thorium. Earth Planet. Sci. Lett. 139, 351-363.

634 Roy-Barman M., Coppola L., and Souhaut M., 2002. Thorium isotopes in the Western Mediterranean 635 Sea: an insight into the marine particle dynamics. Earth Planet Sci. Lett. 196, 161-174.

636 Roy-Barman M., Jeandel C., Souhaut M., Rutgers van der Loeff M., Voege I., Leblond N., and 637 Freydier R., 2005. The influence of particle composition on thorium scavenging in the NE 638 Atlantic ocean (POMME experiment). Earth Planet. Sci. Lett. 240, 681- 693.

639 Sarthou G. and Jeandel C., 2001. Seasonal variations of iron concentrations in the Ligurian Sea and 640 iron budget in the Western Mediterranean Sea. Mar. Chem. 74, 115-129.

641 Schmidt S., Andersen V., Belviso S., and Marty J.-C., 2002. Strong seasonality in particle dynamics 642 of north-western Mediterranean surface waters as revealed by ${ }^{234} \mathrm{Th} /{ }^{238} \mathrm{U}$. Deep Sea Res. 49, $643 \quad 1507-1518$.

644 Schmidt S., Nival P., Reyss J.-L., Baker M., and Buat-Menard P., 1992. Relation between ${ }^{234}$ Th 645 scavenging and zooplancton biomass in Mediterranean surface waters. Oceanol. Acta 15, $227-$ 646231. 
648 V., Sirocko F., Schulzh H., and Ittekkot V., 2005. Radionuclide fluxes in the Arabian Sea: the 649 role of particle composition. Earth Planet. Sci. Lett. 230, 319-337.

650 Scholten J. C., Fietzke_ J., Vogler S., Rutgers van der Loeff_ M. M., Mangini A., Koeve_ W., 651 Waniek_ J., Sto!ers_P., Antia_ A., and Kuss J., 2001. Trapping efficiencies of sediment traps 652 from the deep Eastern North Atlantic: the ${ }^{230}$ Th calibration. Deep-Sea Res. II 48, 2383-2408.

653 Sempéré R., Yoro S. C., Van Wambeke F., and Charrière B., 2000. Microbial decomposition of large 654 organic particles in the northwestern Mediterranean Sea. An experimental approach. Mar. Ecol. 655 Prog. Ser. 198, 61-72.

656 Sicre M.-A., Ternois Y., Miquel J.-C., and Marty J.-C., 1999. Alkenone in the Northwestern 657 Mediterranean sea: interannual variability and vertical transfer. Geophys. Res. Lett. 26, 1735$658 \quad 1738$.

659 Siddall M., Henderson G. M., Edwards N. R., Müller S. A., Stocker T. F., Joos F., and Frank M., $6602005 .{ }^{231} \mathrm{~Pa} /{ }^{230} \mathrm{Th}$ fractionation by ocean transport, biogenic particle flux and particle type. Earth $661 \quad$ Planet. Sci. Lett. 237, 137-155.

662 Stemmann L., Gorsky G., Marty J.-C., Picheral M., and Miquel J.-C., 2002. Four-year study of large663 particle vertical distribution $(0-1000 \mathrm{~m})$ in the NW Mediterranean in relation to hydrology, 664 phytoplankton, and vertical flux. Deep-Sea Res. II 49, 2143-2162.

665 Sternberg E., Jeandel C., Miquel J.-C., Gasser B., Souhaut M., Arraes-Mescoff R., and Francois R., 666 2007. Particulate barium fluxes and export production in the northwestern Mediterranean. Mar. 667 Chem. 105, 281-295.

668 Taylor S. R. and McLennan S. M., 1995. The Geochemical Evolution of the Continental Crust. Rev. 669 Geophys. 33, doi:10.1029/95RG00262. 
670 Ternois Y., Sicre M.-A., Boireau A., Marty J.-C., and Miquel J.-C., 1996. Production pattern of 671 alkenones in the Mediterranean sea. Geophys. Res. Lett. 23(3171-3174).

672 Trimble S. M., Baskarana M., and Porcelli D., 2004. Scavenging of thorium isotopes in the Canada 673 Basin of the Arctic Ocean. Earth. Planet. Sci. Lett. 222, 915-932.

674 Usbeck R., Schlitzer R., Fischer G., and Wefer G., 2003. Particle fluxes in the ocean: comparison of 675 sediment trap data with results from inverse modelling. J. Mar. Systems 39, 167-183.

676 Yu E.-F., Francois R., Bacon M. P., Honjo S., Fleer A. P., Manganini S. J., Rutgers van der Loeff M. 677 M., and Ittekot V., 2001. Trapping effciency of bottom-tethered sediment traps estimated from 678 the intercepted fluxes of ${ }^{230} \mathrm{Th}$ and ${ }^{231} \mathrm{~Pa}$. Deep-Sea Res. I 48, 865-889.

679

680 
681 
Table 1: sediment trap data

\begin{tabular}{|c|c|c|c|c|c|c|c|c|c|c|c|c|c|c|c|}
\hline sample & Sampling dates & $\begin{array}{l}\text { mass flux } \\
\left(\mathrm{mg} / \mathrm{m}^{2} / \mathrm{d}\right)\end{array}$ & $\begin{array}{l}{ }^{232} \mathrm{Th} \\
(\mathrm{ppm})\end{array}$ & $\begin{array}{l}{ }^{230} \mathrm{Th} \\
\text { (ppt) }\end{array}$ & $\begin{array}{c}{ }^{230} \mathrm{Th} /{ }^{232} \mathrm{Th} \\
(\mathrm{mol} / \mathrm{mol})\end{array}$ & $\begin{array}{c}\mathrm{U} \\
\text { (ppm) }\end{array}$ & $\begin{array}{c}\mathrm{U}_{\text {lith }} \\
(\mathrm{ppm})\end{array}$ & $\begin{array}{c}{ }^{230} \mathrm{Th}_{\mathrm{xs}} \\
(\mathrm{ppt})\end{array}$ & $\begin{array}{c}\mathrm{Al} \\
(\mathrm{w} \%)\end{array}$ & $\begin{array}{c}\mathrm{Mn} \\
(\mathrm{ppm})\end{array}$ & $\begin{array}{l}\mathrm{Mn}_{\text {auth }} \\
(\mathrm{ppm})\end{array}$ & $\begin{array}{c}\mathrm{Ba} \\
(\mathrm{ppm}) \\
\end{array}$ & $\begin{array}{c}\mathrm{Ba}_{\mathrm{ex}} \\
(\mathrm{ppm})\end{array}$ & $\begin{array}{l}\mathrm{POC} \\
(\mathrm{w} \%)\end{array}$ & $\begin{array}{c}\mathrm{CaCO}_{3} \\
(\mathrm{w} \%)\end{array}$ \\
\hline \multicolumn{16}{|l|}{$200 \mathrm{~m}$} \\
\hline $1 \mathrm{~B}$ & $15.07 .99-08.08 .99$ & 5.8 & $1.87 \pm 0.01$ & $11.6 \pm 0.8$ & $6.2 \pm 0.4$ & 0.49 & $0.24 \pm 0.25$ & $7.6 \pm 5.0$ & 1.18 & 157 & $58 \pm 12$ & 347 & $268 \pm 20$ & 14 & 47 \\
\hline $2 \mathrm{~B}$ & 09.08.99-05.09.99 & 25.8 & $7.95 \pm 0.05$ & $46.3 \pm 0.7$ & $5.8 \pm 0.1$ & 1.76 & $1.66 \pm 0.12$ & $19.1 \pm 2.6$ & 5.58 & 787 & $315 \pm 58$ & 673 & $300 \pm 76$ & 13 & 14 \\
\hline $3 \mathrm{~B}$ & $06.09 .99-03.10 .99$ & 4.0 & $4.66 \pm 0.02$ & $24.7 \pm 0.9$ & $5.3 \pm 0.2$ & 1.10 & $0.80 \pm 0.31$ & $11.7 \pm 6.0$ & 3.45 & 287 & $-5 \pm 32$ & 454 & $223 \pm 48$ & 9 & 40 \\
\hline $4 \mathrm{~B}$ & $04.10 .99-31.10 .99$ & 16.5 & $5.61 \pm 0.02$ & $30 \pm 1.4$ & $5.4 \pm 0.2$ & 1.28 & $1.08 \pm 0.22$ & $12.6 \pm 5.0$ & 3.91 & 332 & $1 \pm 36$ & 617 & $356 \pm 56$ & 11 & 27 \\
\hline $5 B$ & $01.11 .99-05.12 .99$ & 9.0 & $7.10 \pm 0.02$ & $33.2 \pm 0.9$ & $4.7 \pm 0.1$ & 1.38 & $1.18 \pm 0.21$ & $13.8 \pm 4.4$ & 4.66 & 512 & $117 \pm 46$ & 625 & $313 \pm 65$ & 16 & 27 \\
\hline $6 \mathrm{~B}$ & $13.12 .99-09.01 .00$ & 100 & $8.07 \pm 0.03$ & $34.2 \pm 0.6$ & $4.2 \pm 0.1$ & 1.65 & $1.55 \pm 0.14$ & $8.8 \pm 3.0$ & 5.92 & 852 & $351 \pm 62$ & 548 & $153 \pm 77$ & 11 & 13 \\
\hline $7 \mathrm{~B}$ & $10.01 .00-30.01 .00$ & 97 & $9.85 \pm 0.07$ & $39.7 \pm 0.5$ & $4.0 \pm 0.1$ & 1.86 & $1.75 \pm 0.12$ & $11.0 \pm 2.5$ & 6.99 & 850 & $258 \pm 70$ & 506 & $39 \pm 89$ & 14 & 15 \\
\hline $8 \mathrm{~B}$ & $31.01 .00-20.02 .00$ & 223 & $9.89 \pm 0.07$ & $40 \pm 1.2$ & $4.1 \pm 0.1$ & 2.05 & $1.98 \pm 0.08$ & $7.7 \pm 2.5$ & 6.89 & 872 & $288 \pm 70$ & 333 & $-127 \pm 84$ & 12 & 9 \\
\hline 9B & 21.02 & 222 & $9.34 \pm 0.06$ & $39.3 \pm 0.5$ & $4.2 \pm 0.1$ & 1.98 & $1.89 \pm 0.12$ & $8.4 \pm 2.5$ & 6.45 & 779 & $233 \pm 65$ & 462 & $31 \pm 82$ & 13 & 12 \\
\hline 10B & 13.03 & 315 & $6.38 \pm 0.03$ & $27.8 \pm 0.6$ & $4.4 \pm 0.1$ & 1.35 & $1.30 \pm 0.09$ & $6.5 \pm 2.0$ & 5.37 & 640 & $185 \pm 54$ & 399 & $40 \pm 68$ & 8 & 7 \\
\hline 11B & 03.04 & 813 & $0.90 \pm 0.01$ & $4.9 \pm 0.3$ & $5.4 \pm 0.3$ & 0.43 & $0.34 \pm 0.10$ & $-0.6 \pm 1.8$ & 0.93 & 48 & $-31 \pm 8$ & 321 & $259 \pm 17$ & 4 & 12 \\
\hline $12 \mathrm{~B}$ & $\overline{10.04}$ & 434 & $2.13 \pm 0.01$ & $11.0 \pm 0.3$ & $5.2 \pm 0.1$ & 0.75 & $0.60 \pm 0.16$ & $1.2 \pm 2.8$ & 1.77 & 114 & $-36 \pm 16$ & 264 & $146 \pm 25$ & 14 & 20 \\
\hline 13B & 01.0 & 267 & $1.87 \pm 0.01$ & $10.2 \pm 0.4$ & $5.4 \pm 0.2$ & 0.65 & $49 \pm 0.17$ & $2.2 \pm 3.2$ & 1.79 & 172 & $20 \pm 17$ & 415 & $295 \pm 28$ & 18 & 22 \\
\hline 14B & 22.05 & 134 & $2.00 \pm 0.01$ & $11.6 \pm 0.5$ & $5.8 \pm 0.2$ & 0.64 & $0.50 \pm 0.15$ & $3.5 \pm 2.9$ & 1.62 & 259 & $121 \pm 18$ & 567 & $459 \pm 30$ & 17 & 19 \\
\hline $15 \mathrm{~B}$ & 12.06 & 537 & $1.32 \pm 0.01$ & $8.0 \pm 0.3$ & $6.0 \pm 0.3$ & 0.47 & $0.37 \pm 0.11$ & $1.9 \pm 2.2$ & 0.92 & 133 & $55 \pm 10$ & 343 & $281 \pm 17$ & 31 & 14 \\
\hline $16 \mathrm{~B}$ & 26 & 78 & $1.28 \pm 0.01$ & $8.2 \pm 0.3$ & $6.4 \pm 0.3$ & 0.41 & $0.30 \pm 0.12$ & $3.4 \pm 2.3$ & 0.76 & 124 & $60 \pm 8$ & 276 & $225 \pm 14$ & 29 & 16 \\
\hline 17B & & 536 & $30 \pm 0.01$ & $10.7 \pm 0.4$ & $6.0 \pm 0.2$ & 0.65 & 12 & $2.0 \pm 2.4$ & 1.23 & 127 & $23 \pm 12$ & 377 & $295 \pm 21$ & 29 & 15 \\
\hline \multicolumn{16}{|c|}{$1000 \mathrm{~m}$} \\
\hline $1 \mathrm{~A}$ & 15.07 .9 & 68 & $6.80 \pm 0.13$ & $45 \pm 1.2$ & $6.7 \pm 0.2$ & 1.55 & $1.47 \pm 0.09$ & $21.3 \pm 2.6$ & 5.00 & 871 & $448 \pm 55$ & 823 & $489 \pm 73$ & 12 & 11 \\
\hline $2 \mathrm{~A}$ & 09.08.99-05.09.99 & 123 & $8.10 \pm 0.13$ & $45 \pm 2.6$ & $5.6 \pm 0.3$ & 1.73 & $1.63 \pm 0.11$ & $18.7 \pm 4.3$ & 5.65 & 716 & $237 \pm 57$ & 674 & $296 \pm 77$ & 12 & 13 \\
\hline $3 \mathrm{~A}$ & 06.09.99-03.10.99 & 61 & $6.76 \pm 0.06$ & $40.3 \pm 0.7$ & $6.0 \pm 0.1$ & 1.59 & $1.51 \pm 0.09$ & $15.5 \pm 2.1$ & 4.95 & 638 & $220 \pm 50$ & 643 & $313 \pm 68$ & 12 & 10 \\
\hline $4 \mathrm{~A}$ & 04.10.99-31.10.99 & 42 & $7.51 \pm 0.04$ & $47 \pm 0.6$ & $6.3 \pm 0.1$ & 1.79 & $1.69 \pm 0.11$ & $19.3 \pm 2.3$ & 5.09 & 671 & $240 \pm 52$ & 797 & $457 \pm 73$ & 13 & 12 \\
\hline $5 \mathrm{~A}$ & $01.11 .99-05.12 .99$ & 9.8 & $6.82 \pm 0.04$ & $42 \pm 1.0$ & $6.2 \pm 0.2$ & 1.59 & $1.50 \pm 0.10$ & $17.7 \pm 2.6$ & 4.67 & 610 & $215 \pm 48$ & 679 & $367 \pm 66$ & 10 & 11 \\
\hline $6 \mathrm{~A}$ & $13.12 .99-09.01 .00$ & 8.3 & $4.89 \pm 0.02$ & $27 \pm 1.1$ & $5.5 \pm 0.2$ & 1.08 & $0.96 \pm 0.14$ & $11.0 \pm 3.4$ & 3.52 & 449 & $151 \pm 36$ & 471 & $236 \pm 49$ & 17 & 16 \\
\hline $7 \mathrm{~A}$ & $10.01 .00-30.01 .00$ & 20 & $9.21 \pm 0.03$ & $41 \pm 1$ & $4.4 \pm 0.1$ & 1.78 & $1.71 \pm 0.08$ & $12.7 \pm 2.3$ & 6.45 & 821 & $275 \pm 66$ & 575 & $144 \pm 84$ & 10 & 9 \\
\hline $8 \mathrm{~A}$ & $31.01 .00-20.02 .00$ & 165 & $4.80 \pm 0.01$ & $32.4 \pm 0.5$ & $6.8 \pm 0.1$ & 1.40 & $1.36 \pm 0.05$ & $10.3 \pm 1.4$ & 3.91 & 509 & $179 \pm 40$ & 784 & $523 \pm 60$ & 9 & 5 \\
\hline $9 \mathrm{~A}$ & 21.02.00-12.03.00 & 129 & $9.39 \pm 0.10$ & $43.9 \pm 0.7$ & $4.7 \pm 0.1$ & 2.06 & $2.02 \pm 0.06$ & $10.9 \pm 1.7$ & 6.61 & 857 & $297 \pm 68$ & 502 & $60 \pm 84$ & 8 & 6 \\
\hline $10 \mathrm{~A}$ & $13.03 .00-26.03 .00$ & 283 & $8.81 \pm 0.06$ & $42.4 \pm 0.7$ & $4.8 \pm 0.1$ & 1.90 & $1.86 \pm 0.06$ & $12.1 \pm 1.8$ & 6.02 & 801 & $291 \pm 62$ & 479 & $76 \pm 77$ & 9 & 6 \\
\hline $11 \mathrm{~A}$ & $03.04 .00-09.04 .00$ & 298 & $2.74 \pm 0.02$ & $17.5 \pm 0.5$ & $6.4 \pm 0.2$ & 1.00 & $0.90 \pm 0.12$ & $2.8 \pm 2.5$ & 2.24 & 244 & $54 \pm 22$ & 491 & $341 \pm 35$ & 5 & 13 \\
\hline $12 \mathrm{~A}$ & $10.04 .00-01.05 .00$ & 311 & $3.55 \pm 0.03$ & $22.9 \pm 0.4$ & $6.4 \pm 0.1$ & 1.18 & $1.10 \pm 0.08$ & $4.8 \pm 1.8$ & 3.04 & 333 & $76 \pm 30$ & 507 & $304 \pm 44$ & 9 & 10 \\
\hline $13 \mathrm{~A}$ & $01.05 .00-21.05 .00$ & 227 & $9.32 \pm 0.03$ & $42.1 \pm 0.5$ & $4.5 \pm 0.1$ & 1.96 & $1.88 \pm 0.10$ & $11.2 \pm 2.2$ & 6.76 & 921 & $349 \pm 70$ & 438 & $-14 \pm 85$ & 12 & 10 \\
\hline $14 \mathrm{~A}$ & $22.05 .00-11.06 .00$ & 289 & $3.06 \pm 0.01$ & $22.5 \pm 0.4$ & $7.4 \pm 0.1$ & 0.80 & $0.70 \pm 0.11$ & $11.1 \pm 2.2$ & 2.60 & 304 & $84 \pm 26$ & 587 & $413 \pm 41$ & 16 & 13 \\
\hline $15 \mathrm{~A}$ & $12.06 .00-25.06 .00$ & 528 & $2.81 \pm 0.03$ & $19.5 \pm 0.5$ & $6.9 \pm 0.2$ & 0.85 & $0.77 \pm 0.09$ & $6.9 \pm 2.0$ & 2.11 & 355 & $176 \pm 23$ & 576 & $435 \pm 35$ & 25 & 11 \\
\hline $16 \mathrm{~A}$ & $26.06 .00-09.07 .00$ & 277 & $2.79 \pm 0.01$ & $19.3 \pm 0.4$ & $6.9 \pm 0.2$ & 0.70 & $0.60 \pm 0.10$ & $9.4 \pm 2.0$ & 2.07 & 389 & $213 \pm 24$ & 721 & $582 \pm 38$ & 27 & 12 \\
\hline $17 \mathrm{~A}$ & $10.07 .00-16.07 .00$ & 422 & $4.30 \pm 0.02$ & $28.8 \pm 0.6$ & $6.7 \pm 0.1$ & 1.07 & $0.95 \pm 0.13$ & $13.2 \pm 2.8$ & 3.27 & 450 & $174 \pm 34$ & 846 & $628 \pm 54$ & 21 & 16 \\
\hline
\end{tabular}


Table 2: Partition coefficient of Th between lithogenic particles, $\mathrm{MnO}_{2}$ and seawater

\begin{tabular}{|l|c|c|}
\hline & $\mathrm{K}_{\mathrm{d}-\mathrm{litho}}{ }^{\mathrm{Th}}\left(10^{7} \mathrm{ml} / \mathrm{g}\right)$ & $\mathrm{K}_{\mathrm{d}-\mathrm{MnO} 2}{ }^{\mathrm{Th}}\left(10^{10} \mathrm{ml} / \mathrm{g}\right)$ \\
\hline DYFAMED $1000 \mathrm{~m}$, main correlation (this work) & $0.8 \pm 0.2$ & $1.1 \pm 0.4$ \\
\hline DYFAMED 1000 m, winter samples (this work) & $0.42 \pm 0.04$ & $0.6 \pm 0.1$ \\
\hline Eastern North Atlantic $^{1}$ & 5 & 2 \\
\hline Eastern North Atlantic & \\
\hline North Atlantic $^{3}$ & $0.5-10$ & $0.7-4.2$ \\
\hline Equatorial Pacific and Southern Ocean $^{4}$ & 1 & \\
\hline Equatorial Pacific and Southern Ocean $^{5}$ & 23 & 3.5 \\
\hline Panama Basin $^{6}$ & 20 & $0.6-3.7$ \\
\hline
\end{tabular}

${ }^{1}$ Roy-Barman et al., 2005. ${ }^{2}$ Scholten et al., 2001; Kuss and Kremling, 1999. ${ }^{3}$ Chase et al., 2002. ${ }^{4}$ Luo and Ku, 2004a; Luo and Ku, 2004b. ${ }^{5}$ Luo and Ku, 1999, (unpublished data, 1993, http://usjgofs.whoi.edu/jg/dir/jgofs/eqpac/tt013/. ${ }^{6}$ Anderson et al., 1983 (restricted to the samples with a sufficient $\mathrm{Mn}_{\text {auth }}$ content). 


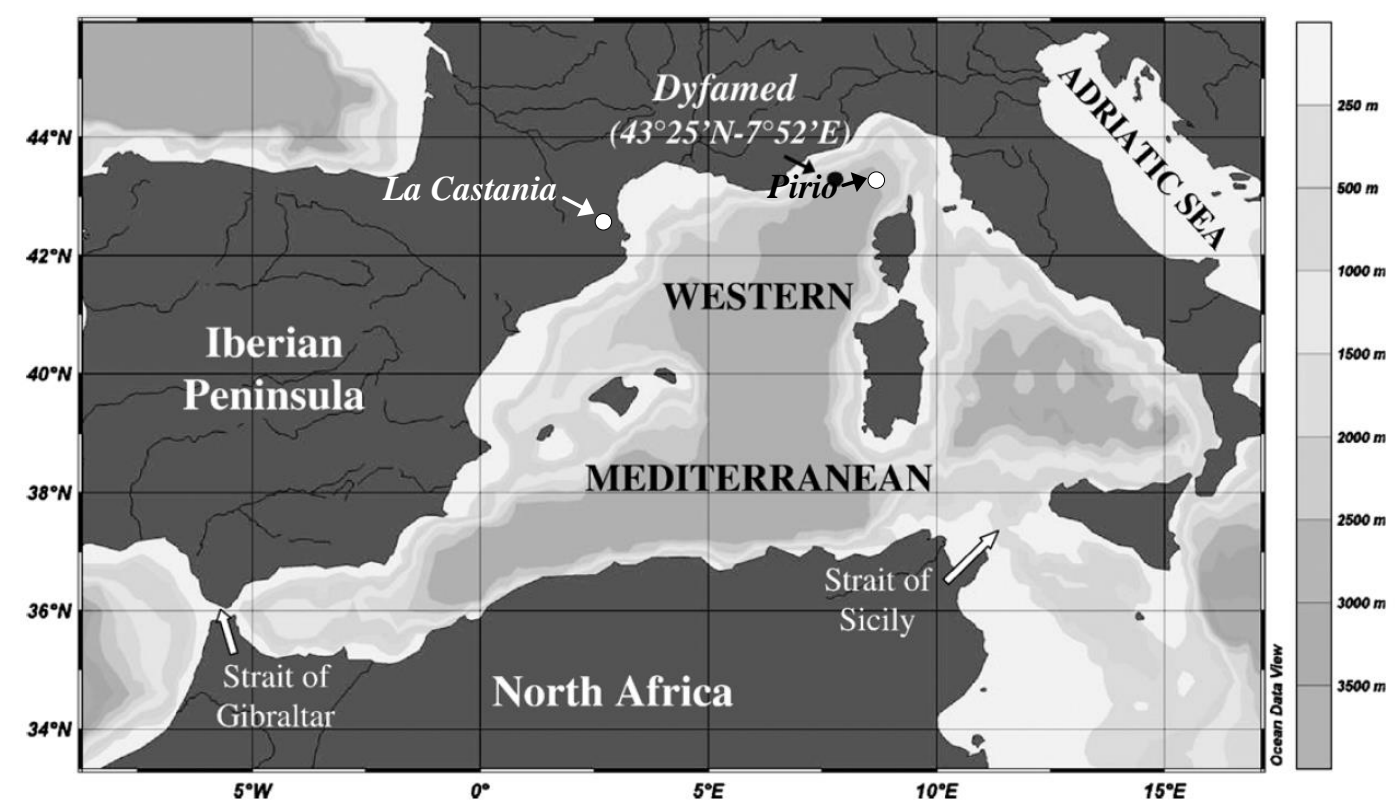

Figure 1 


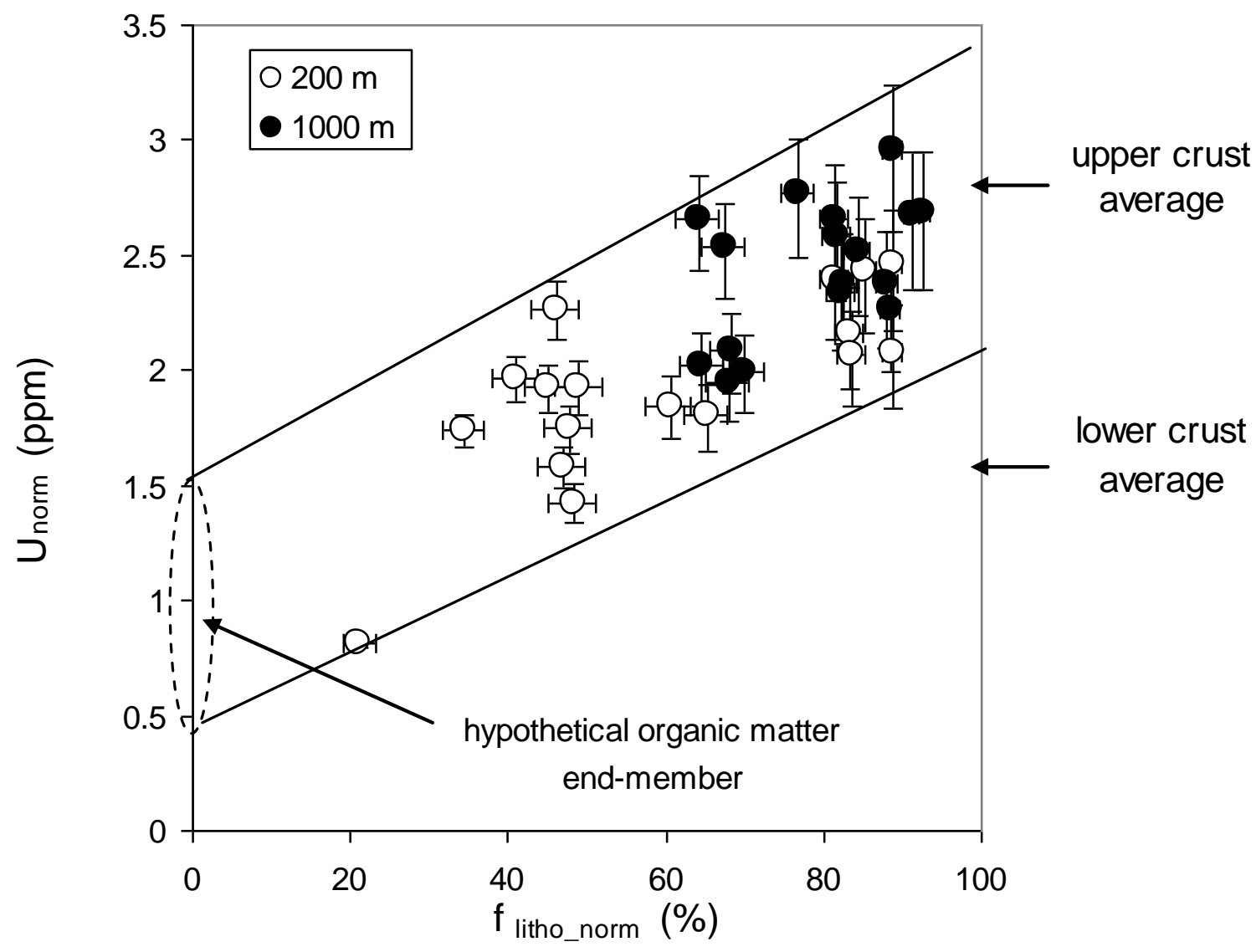

Figure 2 

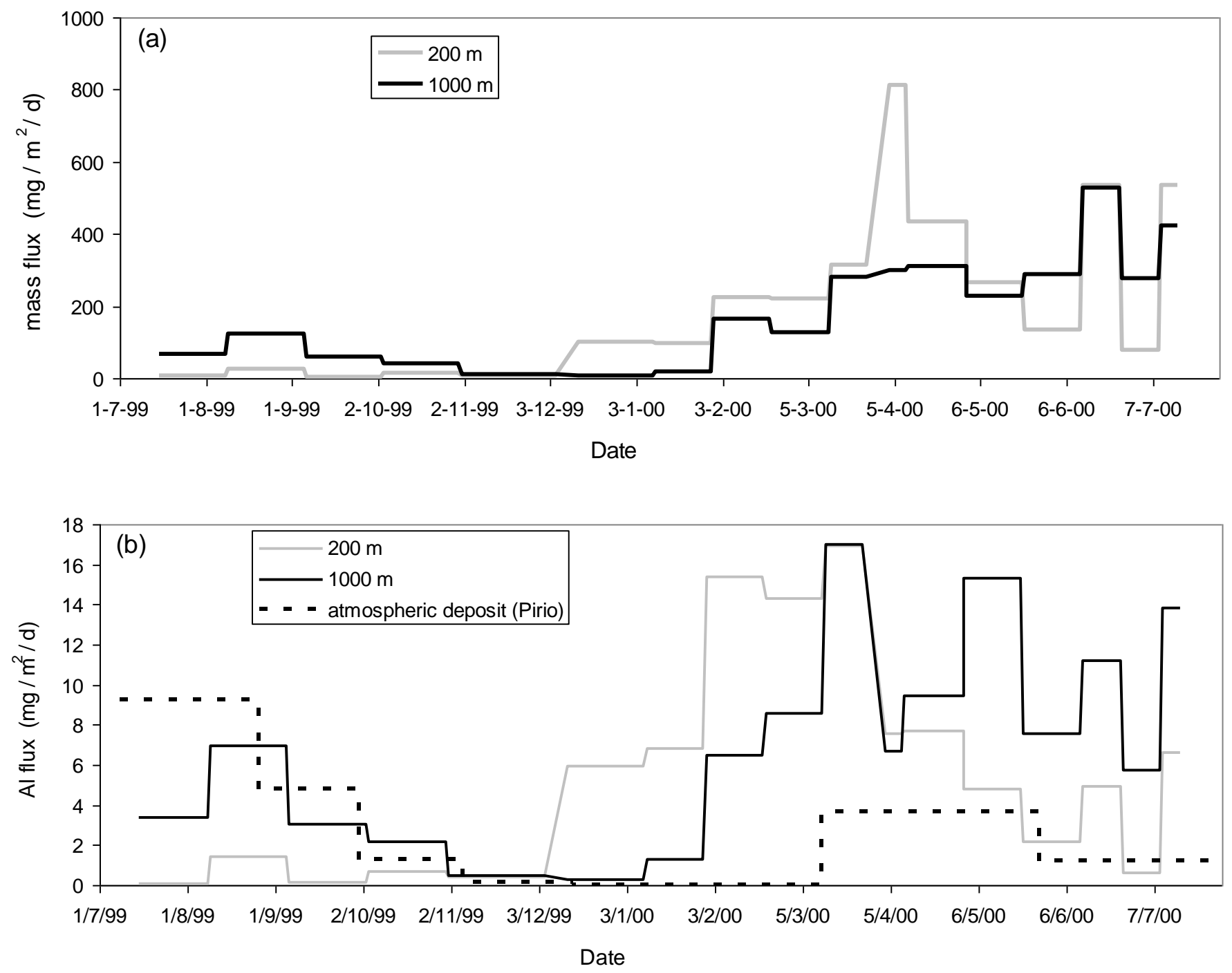

Figure 3 

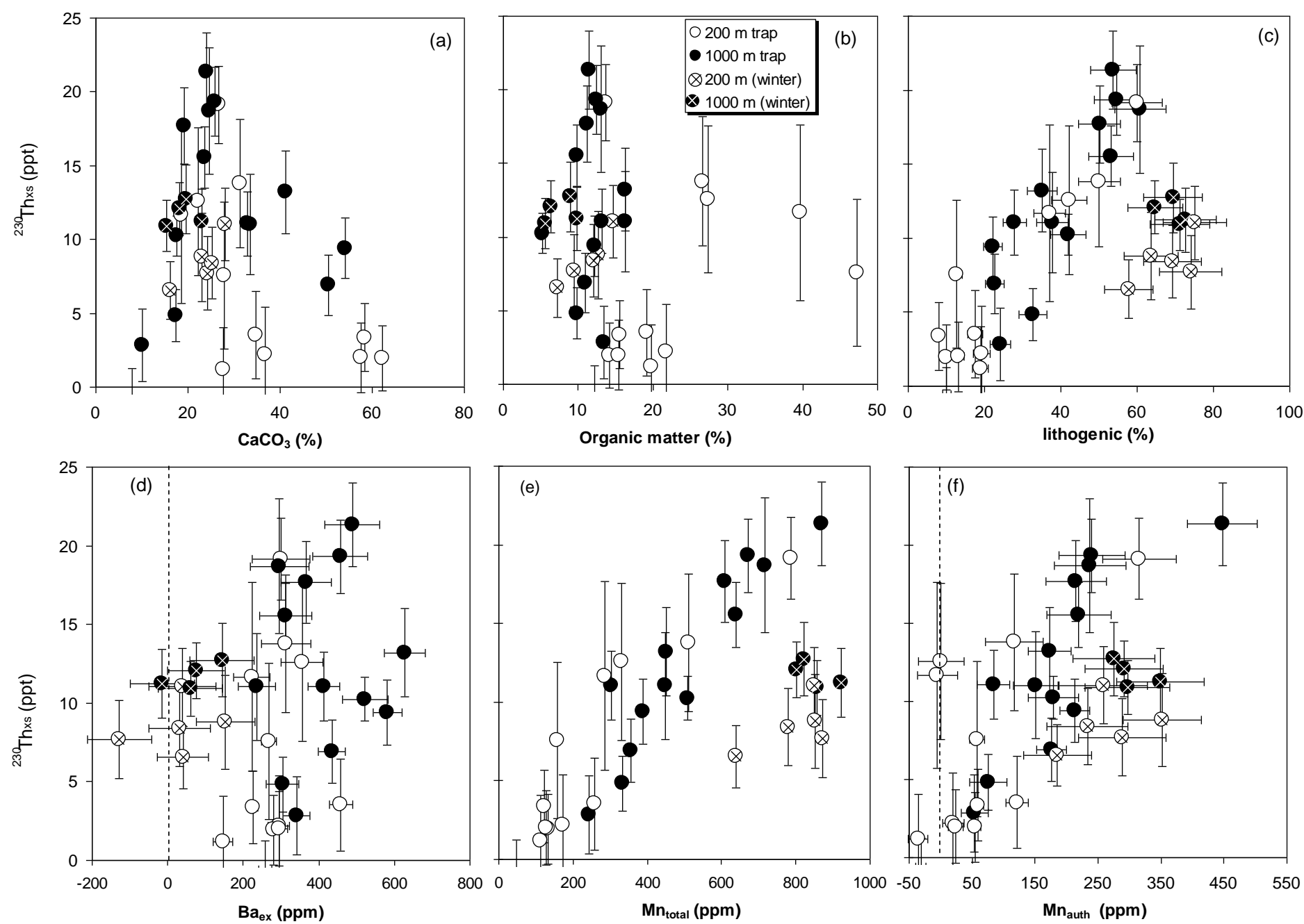

Figure 4 